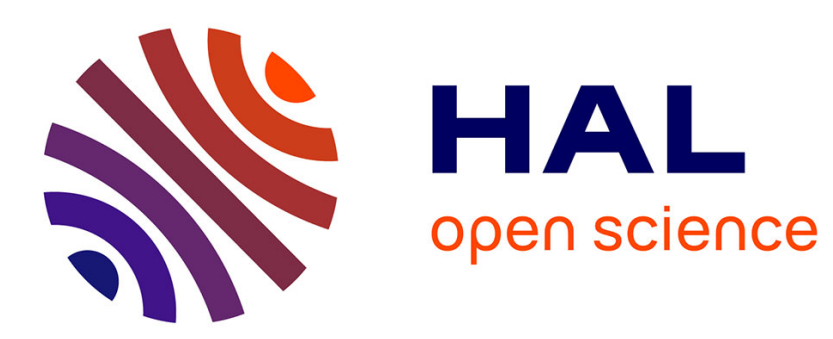

\title{
Observations of total alkyl nitrates within the Sacramento Urban Plume
}

P. A. Cleary, J. G. Murphy, P. J. Wooldridge, D. A. Day, D. B. Millet, M. Mckay, A. H. Goldstein, R. C. Cohen

\section{- To cite this version:}

P. A. Cleary, J. G. Murphy, P. J. Wooldridge, D. A. Day, D. B. Millet, et al.. Observations of total alkyl nitrates within the Sacramento Urban Plume. Atmospheric Chemistry and Physics Discussions, 2005, 5 (4), pp.4801-4843. hal-00301616

\section{HAL Id: hal-00301616 https://hal.science/hal-00301616}

Submitted on 13 Jul 2005

HAL is a multi-disciplinary open access archive for the deposit and dissemination of scientific research documents, whether they are published or not. The documents may come from teaching and research institutions in France or abroad, or from public or private research centers.
L'archive ouverte pluridisciplinaire HAL, est destinée au dépôt et à la diffusion de documents scientifiques de niveau recherche, publiés ou non, émanant des établissements d'enseignement et de recherche français ou étrangers, des laboratoires publics ou privés. 


\section{Observations of total alkyl nitrates within the Sacramento Urban Plume}

P. A. Cleary ${ }^{1,{ }^{\star}}$, J. G. Murphy ${ }^{1}$, P. J. Wooldridge ${ }^{1}$, D. A. Day ${ }^{1,{ }^{\star \star}}$, D. B. Millet ${ }^{2,{ }^{\star \star \star}}$, M. McKay ${ }^{2}$, A. H. Goldstein ${ }^{2,4}$, and R. C. Cohen ${ }^{1,3,4}$

${ }^{1}$ Department of Chemistry, University of California, Berkeley, Berkeley, CA 94720, USA

${ }^{2}$ Department of Environmental Science, Policy and Management, University of California, Berkeley, Berkeley, CA 94720, USA

${ }^{3}$ Department of Earth and Planetary Science, University of California, Berkeley, Berkeley, CA 94720, USA

${ }^{4}$ Environment Technologies Division, Lawrence Berkeley National Laboratory, Berkeley, CA 94720, USA

"now at: Department of Chemistry, University of Leeds, Leeds LS2 9JT, UK

*kow at: Department of Land, Air, and Water Resources, University of California, Davis,

Davis, CA, USA

now at: Department of Earth and Planetary Sciences, Harvard University, Cambridge, MA 02138, USA

Received: 4 April 2005 - Accepted: 2 June 2005 - Published: 13 July 2005

Correspondence to: R. C. Cohen (cohen@cchem.berkeley.edu)

(C) 2005 Author(s). This work is licensed under a Creative Commons License.
$5,4801-4843,2005$

Total alkyl nitrates within the

\section{Sacramento Urban}

Plume

P. A. Cleary et al.

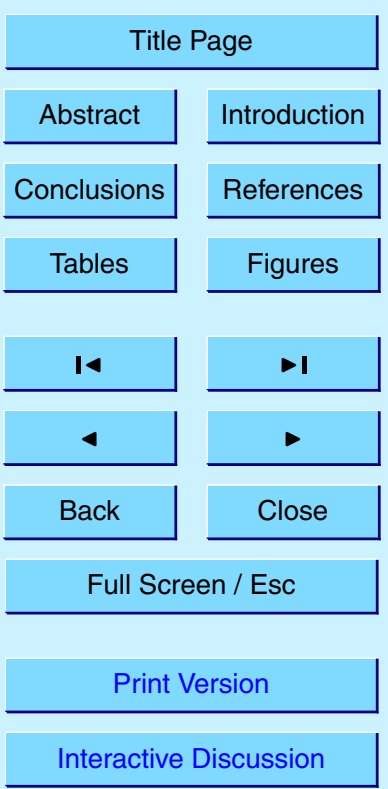




\section{Abstract}

During the summer of 2001, $\mathrm{NO}_{2}$, total peroxy nitrates ( $\Sigma \mathrm{PNs}$ ), total alkyl nitrates ( $\Sigma \mathrm{ANs}$ ), $\mathrm{HNO}_{3}$, volatile organic compounds (VOC), $\mathrm{CO}_{2}, \mathrm{O}_{3}$, and meteorological variables were measured at Granite Bay, CA. The diurnal variation in $\Sigma P N s, \Sigma A N s$ and

$5 \mathrm{HNO}_{3}$ were all strongly correlated with sunlight, indicating both that they are photochemically produced and that they have a lifetime of a few hours at this site. The mixing ratios of $\Sigma A N s$ ranged as high as $2 \mathrm{ppbv}$. Mixing ratios at night averaged $0.4 \mathrm{ppbv}$. Oddoxygen $\left(\mathrm{O}_{\mathrm{x}}=\mathrm{O}_{3}+\mathrm{NO}_{2}\right)$ and $\Sigma \mathrm{ANs}$ were strongly correlated reflecting both the common chemical source terms and the similar lifetimes of both species. Several approaches

to interpreting the simultaneous variations of $O_{x}$ and $\Sigma A N s$ are described, and used to derive a best estimate of the $\Sigma A N$ yield from the VOC mixture at this site of $4.2 \%$ and an estimate of the range that is consistent with the observations of 3.9-5.8\%. A yield of $4.2 \%$ implies termination of the $\mathrm{HO}_{\mathrm{x}}$ catalytic cycle by $\Sigma \mathrm{AN}$ formation once every 24 cycles. Analysis of the $\mathrm{HNO}_{3}$ observations in combination with the $\Sigma \mathrm{AN}$ and $\mathrm{O}_{3}$ 15 measurements suggests that $\mathrm{NO}_{\mathrm{x}}$ terminations limit the $\mathrm{HO}_{\mathrm{x}}$ chain length to between 4.7 and 6.3 .

\section{Introduction}

The CATSUP (Chemistry and Transport of the Sacramento Urban Plume)-2001 experiment was designed to provide observations that constrain chemical reactions, transport and source terms affecting atmospheric composition within the Sacramento urban plume. The project combined two field sites: one at Granite Bay, CA, a town on the eastern edge of the Sacramento urban sprawl, and a second site $5 \mathrm{~h}$ downwind at the University of California Blodgett Forest Research Station (UC-BFRS) (Fig. 1). The two sites are routinely connected in a Lagrangian sense by the predominant air-flow trajectories, permitting detailed examination of effects of chemistry and transport on changes in composition of the Sacramento urban plume.
ACPD

$5,4801-4843,2005$

Total alkyl nitrates within the

\section{Sacramento Urban} Plume

P. A. Cleary et al.

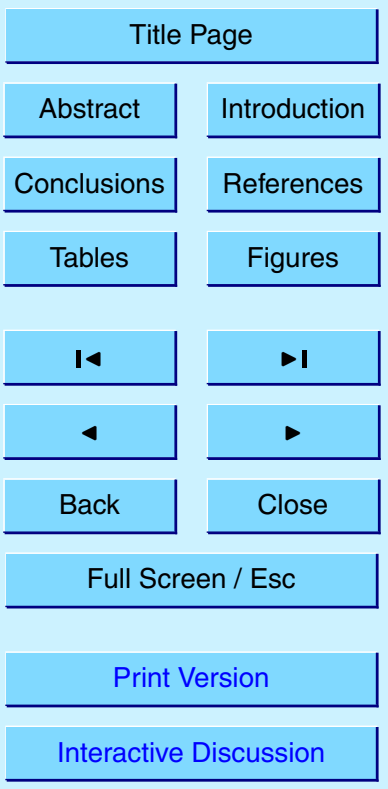


In this manuscript we focus on the initial conditions of this evolving plume. We describe observations of nitrogen oxides at the Granite Bay location and we emphasize analyses of the total alkyl nitrate $(\Sigma A N)$ measurements which are of interest because:

1) models show that production of $\Sigma A N$ from these precursors represents a major sink of odd-nitrogen in the eastern US (Liang et al., 1998; Luecken et al., 1999; Poschl et al., 2000; Shepson et al., 1996; Sillman et al., 1998; Trainer et al., 1991) and observations show they are a major component of odd-nitrogen on the western slopes of the Sierra Nevada Mountains (Day et al., 2003);

2) they are closely connected to $\mathrm{RO}_{2}$, molecules that are central to the $\mathrm{HO}_{\mathrm{x}}$ catalytic cycle but that are not well documented by observations;

3) formation of $\Sigma A N s$ can be a major termination of the $\mathrm{HO}_{\mathrm{x}}$ and $\mathrm{NO}_{\mathrm{x}}$ catalytic cycles; yet the effects of this termination has not been extensively studied, presumably because of the lack of observations to constrain it and

4) $\Sigma$ ANs partially determine the extent to which urban emissions of $\mathrm{NO}_{\mathrm{x}}$ are redistributed to larger spatial scales (Bertman et al., 1995).

Recent observations of $\Sigma$ ANs using the Berkeley TD-LIF instrument have shown that $\Sigma$ ANs are likely all, or at least a majority of, the 'missing $\mathrm{NO}_{y}$ ' (Day et al., 2003) and that they are important controls over the fate of $\mathrm{NO}_{\mathrm{x}}$ in urban plumes (Rosen et al., 2004). Mechanistic analyses described in those manuscripts indicate that one of the key diagnostics for understanding the temporal and spatial behavior of $\Sigma$ ANs both in models and in the atmosphere will be their correlation with $\mathrm{O}_{\mathrm{x}}\left(\mathrm{O}_{\mathrm{x}}=\mathrm{O}_{3}+\mathrm{NO}_{2}\right)$. Rosen et al. (2004) described observations obtained at La Porte, TX, where the observed correlation of $\mathrm{O}_{\mathrm{x}}$ with $\Sigma A N$ s from 09:00-12:00 local time had a slope of 29 implying a $\Sigma$ AN yield of $6.5 \%$ for the VOC mix at the site. The calculated yield for the observed VOC mix was $4.5 \%$. In this paper, we build on this prior work, using observations of meteorological variables, $\mathrm{O}_{3}$, nitrogen oxides and VOC to investigate $\Sigma A N, \mathrm{O}_{3}$ and nitrogen oxide photochemistry at Granite Bay, CA. The $\mathrm{O}_{3}$ and $\Sigma A N$ data are used to 4803
ACPD

$5,4801-4843,2005$

\section{Total alkyl nitrates within the \\ Sacramento Urban Plume}

P. A. Cleary et al.

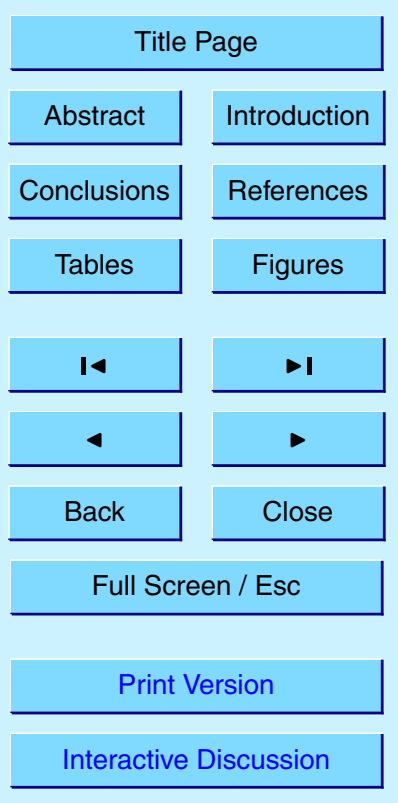

EGU 
assess the alkyl nitrate yield from the VOC mixture at Granite Bay, and this correlation is studied with respect to background or nighttime effects. The VOC observations are used to model the expected alkyl nitrate yield and net $\mathrm{O}_{3}$ and $\Sigma \mathrm{AN}$ production rates. The production rates help to investigate how mixing effects the rise in $\mathrm{O}_{3}$ and $\Sigma$ ANs 5 over the morning. Finally, we also use a reduced representation of $\mathrm{NO}_{x}$ oxidation by the sum of only $\mathrm{HNO}_{3}$ and $\Sigma \mathrm{ANs}$ to estimate chain length of $\mathrm{HO}_{\mathrm{x}}$ and $\mathrm{NO}_{\mathrm{x}}$ cycles at this location.

\section{Experimental}

Observations of $\mathrm{NO}_{2}$, total peroxy nitrates ( $\Sigma \mathrm{PNs}$ ), $\Sigma \mathrm{ANs}, \mathrm{HNO}_{3}, \mathrm{O}_{3}, \mathrm{VOC}$, and mete10 orological variables were collected from 19 July-15 September 2001 on the property

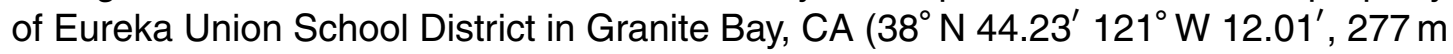
above sea level). This site is located $30 \mathrm{~km}$ north-east of Sacramento, CA, at the eastern edge of the suburban sprawl (Fig. 1) and between two major highways: Interstate $80,8 \mathrm{~km}$ to the north and Highway $50,13 \mathrm{~km}$ to the south. The instruments 5 were housed in a temperature-controlled trailer with inlets mounted on a rooftop tower $7 \mathrm{~m}$ above the ground (1-2 $\mathrm{m}$ above the trailer). The meteorological sensors for wind speed, wind direction, relative humidity and temperature (RM Young model 05103 and Vaisala $\mathrm{RH} / \mathrm{T}$ sensor model HMP45A) were also located on the tower. Photosynthetically Active Radiation (PAR) was observed using a LICOR LI190SZ Quantum Sensor. $\mathrm{O}_{3}$ was measured with a Dasibi 1008 ultraviolet photometric ozone analyzer.

Skies were clear on all but two days of the campaign. Wind patterns observed at the site were quite regular, at speeds of $2-2.4 \mathrm{~m} / \mathrm{s}$ from the southwest (directly from Sacramento) during the afternoon (12:00-17:00) and from the southeast at $1.6 \mathrm{~m} / \mathrm{s}$ (downslope from the Sierra Nevada) at night (20:00-06:00). On most days, the wind direction rotated smoothly and continuously from southeasterlies to southwesterlies between the hours of 0600-1200h and then rotated back between 17:00 and 20:00. On these days temperature usually was below $16^{\circ} \mathrm{C}$ in the morning. On days where
ACPD

$5,4801-4843,2005$

Total alkyl nitrates within the

Sacramento Urban Plume

P. A. Cleary et al.

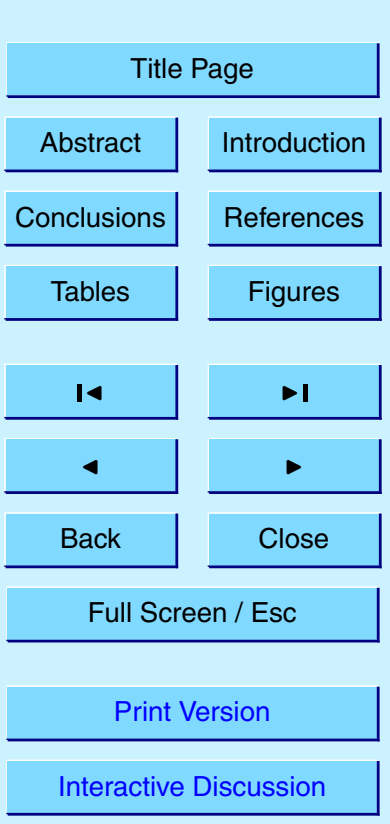

EGU 
nighttime cooling was not as strong, the change in wind direction was more abrupt with stagnating wind speeds at 05:00-07:00 followed by a rapid rotation from the nighttime to the daytime direction. Back trajectories were calculated using the HYSPLIT model (NOAA-ARL, 1997) at hourly intervals for several days of the campaign. Most of the $58 \mathrm{~h}$ back trajectories in the morning were similar with air masses originating southeast of the site. At 8 a.m., most trajectories travel linearly from the southeast of Granite Bay $\left(130^{\circ}\right)$ (Line 1, Fig. 1). Later in the morning, at roughly 10 a.m., the air parcels that were originally following streamlines from the southeast turn and arrive at Granite Bay from the southwest $\left(200^{\circ}\right)$ (Line 2, Fig. 1). By noon, the air parcels observed 10 at Granite Bay were ones that arrived at the Sacramento urban core from the South and then turned toward Granite Bay traveling over the entire length of the Sacramento metropolitan region (Line 3, Fig. 1). On warmer days, the wind turns toward Granite Bay earlier in the day. Temperatures (mean $\pm 1 \sigma$ ) at Granite Bay during the campaign were $16( \pm 2.4)^{\circ} \mathrm{C}$ at 05:00 LT rising to $33( \pm 3.6)^{\circ} \mathrm{C}$ at 16:00 LT. On a few occasions, the

trajectories indicated that the air parcels arrived at Granite Bay after traveling across the central valley to the north or south of the Sacramento metropolitan area. There were clear differences in the ozone and nitrogen oxide observations on these days as described below.

\subsection{Nitrogen oxides}

$20 \mathrm{NO}_{2}$ was measured continuously by LIF using a continuous-wave tunable diode laser instrument with sensitivity of $145 \mathrm{pptv} / \mathrm{min}$ as described by Cleary et al. (2002). The instrument uses a $15 \mathrm{~mW} \mathrm{cw}$ diode laser to excite ambient $\mathrm{NO}_{2}$ at an isolated rovibronic line near $640 \mathrm{~nm}$. The subsequent fluorescence of $\mathrm{NO}_{2}$ is imaged onto a photomultiplier tube at $90^{\circ}$ from the laser path. The fluorescence signal is enhanced by the use 25 of a supersonic expansion, cooling the $\mathrm{NO}_{2}$ to $25-50 \mathrm{~K}$ with a consequent increase of about a factor of 30 in the population of the rotational state excited by the laser.

$\mathrm{NO}_{2}, \Sigma \mathrm{PNs}, \Sigma$ ANs and $\mathrm{HNO}_{3}$ were measured using a two-channel ThermalDissociation Laser Induced Fluorescence (TD-LIF) instrument as described by Day et
ACPD

$5,4801-4843,2005$

Total alkyl nitrates within the

Sacramento Urban Plume

P. A. Cleary et al.

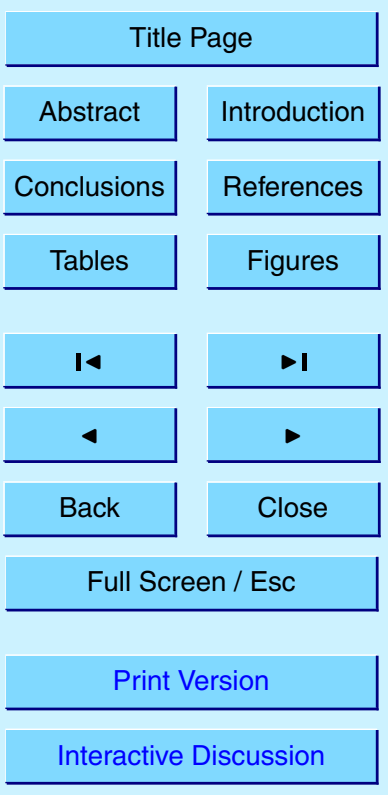

EGU 
al. (2002). Briefly, an ambient sample flows rapidly through two ovens causing dissociation of $\mathrm{NO}_{\mathrm{Z}}\left(\mathrm{NO}_{\mathrm{Z}} \equiv \mathrm{HNO}_{3}+\Sigma \mathrm{ANs}+\Sigma \mathrm{PNs}\right)$ species to $\mathrm{NO}_{2}$. The inlet tip is constructed from PFA Teflon tubing and fittings, with a port for calibration and zeroing followed by a split to the two ovens. The tip is kept as compact as possible, and is thermostatted at $5>50^{\circ} \mathrm{C}$ to ensure high $\mathrm{HNO}_{3}$ transmission even under high relative humidity conditions. Three different temperatures are used: $180^{\circ} \mathrm{C}, 350^{\circ} \mathrm{C}$ and $550^{\circ} \mathrm{C}$, to observe the three distinct classes of $\mathrm{NO}_{\mathrm{z}}$ : $\Sigma \mathrm{PNs}, \Sigma \mathrm{ANs}$ and $\mathrm{HNO}_{3}$. The $\mathrm{NO}_{2}$ signal is the sum of the $\mathrm{NO}_{2}$ contained in all $\mathrm{NO}_{\mathrm{z}}$ species that dissociate at or below the oven temperature. The difference between the $\mathrm{NO}_{2}$ observed in two separate channels at adjacent tem10 perature set points is associated with a specific class of compounds. For these TD-LIF measurements $\mathrm{NO}_{2}$ was measured using a pulsed dye laser with time gated detection (Thornton et al., 2000). The sensitivity to $\mathrm{NO}_{2}$ was $15 \mathrm{pptv} \mathrm{s}^{-1}$ and the sensitivity for $\Sigma$ PNs, $\Sigma$ ANs and $\mathrm{HNO}_{3}$ was typically $45 \mathrm{pptv} \mathrm{min}^{-1}, 54 \mathrm{pptv} \mathrm{min}^{-1}$, and $70 \mathrm{pptv} \mathrm{min}^{-1}$ (Day et al., 2002; Rosen et al., 2004).

15 Both instruments were calibrated several times daily by dynamically diluting an $\mathrm{NO}_{2}$ standard (Scott Specialty Gases, $19.2 \mathrm{ppb})$ in dry $\mathrm{NO}_{x}$-free air $\left(\mathrm{NO}_{x}=\mathrm{NO}+\mathrm{NO}_{2}\right)$. The accuracy of the standard was established by comparison to a library of 6 other standards before and after the campaign. Standard addition of $\mathrm{NO}_{2}$ was used as a check that the effects of humidity on $\mathrm{NO}_{2}$ fluorescence and that small $(<15 \%)$ effects due to 20 secondary chemistry that occurs in the inlet of the TD-LIF instrument were accurately accounted for in the data analysis (Rosen et al., 2004). The overall accuracy is $\pm 15 \%$ for each compound class. About half of the systematic uncertainties in the individual classes of $\mathrm{NO}_{\mathrm{yi}}$ observed by TD-LIF are correlated, in the sense that if $\Sigma$ ANs are too high, then $\mathrm{NO}_{2}, \Sigma \mathrm{PNs}$, and $\mathrm{HNO}_{3}$ are also too high by the same percentage. Labora25 tory experiments on aerosol $\mathrm{NH}_{4} \mathrm{NO}_{3}$ and $\mathrm{NaNO}_{3}$ show that the $\mathrm{HNO}_{3}$ measurements are the sum of gas and semi-volatile aerosol nitrate but that TD-LIF is blind to nonvolatile salts such as $\mathrm{NaNO}_{3}$ (Bertram and Cohen, 2003). Thus our measurements of $\Sigma$ ANs are the total $\Sigma A N s$ independent of whether they are gas and aerosol $\Sigma A N s$ and the $\mathrm{HNO}_{3}$ we report is the sum of gas phase $\mathrm{HNO}_{3}$ and semivolatile aerosol nitrate.

ACPD

$5,4801-4843,2005$

\section{Total alkyl nitrates within the \\ Sacramento Urban Plume}

P. A. Cleary et al.

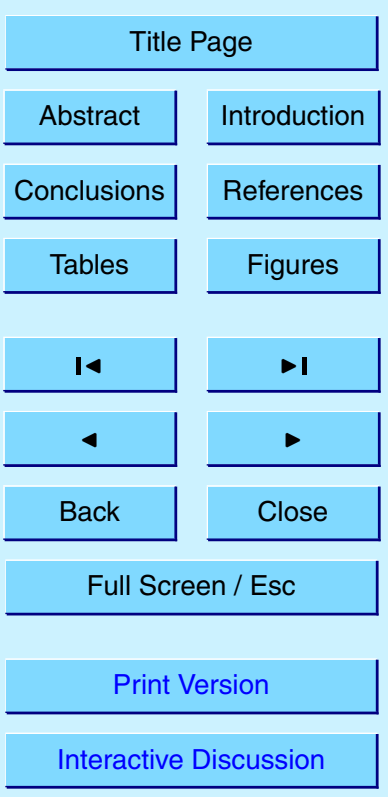

EGU 
We did not measure $\mathrm{NO}$ or $\mathrm{NO}_{\mathrm{y}}$ directly. For the purpose of this paper, we calculate $\mathrm{NO}$ using a photostationary state approximation (Eq. 1) and the concurrent $\mathrm{NO}_{2}$ and $\mathrm{O}_{3}$ measurements:

$[\mathrm{NO}]_{S S}=\frac{J\left[\mathrm{NO}_{2}\right]}{k_{\mathrm{O}_{3}+\mathrm{NO}}\left[\mathrm{O}_{3}\right]}$

5 The photolysis rate of $\mathrm{NO}_{2}$ is estimated using calculations with the TUV model (UCAR, 2002). The effect of peroxy radicals on the conversion of $\mathrm{NO}$ to $\mathrm{NO}_{2}$ is neglected. Thus our estimates of $\mathrm{NO}$ are likely too large by $10-30 \% . \Sigma \mathrm{NO}_{\mathrm{yi}}$ is calculated as the sum of $\mathrm{NO}_{s s}+\mathrm{NO}_{2}+\Sigma \mathrm{PNs}+\Sigma \mathrm{ANs}+\mathrm{HNO}_{3}$. As $\mathrm{NO}$ is usually a small fraction of $\mathrm{NO}_{\mathrm{y}}$ at this site $(5-10 \%)$, the uncertainty in $\mathrm{NO}$ does not affect any of the conclusions about $\Sigma \mathrm{NO}_{\mathrm{yi}}$

10 presented here. Also, $\mathrm{O}_{3}$ and $\mathrm{NO}_{2}$ are in a rapid steady-state making $\mathrm{O}_{\mathrm{x}}\left(\mathrm{O}_{\mathrm{x}} \equiv \mathrm{NO}_{2}+\mathrm{O}_{3}\right)$ a more conserved quantity than $\mathrm{O}_{3}$. For this reason we consider $\mathrm{O}_{x}$ rather than $\mathrm{O}_{3}$ in the following analysis.

\subsection{VOC Measurements}

Volatile organic compounds were measured hourly with a fully automated, in situ, 15 two-channel gas chromatograph/mass selective detector/flame ionization detector (GC/MSD/FID) system. This system is described in detail elsewhere (Millet et al., 2004). Briefly, the FID channel was configured for analysis of $C_{3}-C_{6}$ alkanes, alkenes, and alkynes, and the MSD channel for analysis of a range of other VOC, including aromatic, oxygenated and halogenated compounds. For $36 \mathrm{~min}$ out of every hour, two subsample flows $(15 \mathrm{ml} / \mathrm{min})$ were drawn from the main sample line (4 liters $/ \mathrm{min})$ and passed through a preconditioning trap for the removal of water $\left(-25^{\circ} \mathrm{C}\right.$ cold trap). Carbon dioxide and ozone were scrubbed from the FID channel subsample (Ascarite II), and ozone was removed from the MSD channel subsample (KI impregnated glass wool). Preconcentration was accomplished using a combination of thermoelectric cooling $\left(-15^{\circ} \mathrm{C}\right)$ and adsorbent trapping. Samples were injected into the $\mathrm{GC}$ by rapidly heating the trap assemblies to $200^{\circ} \mathrm{C}$. The instrument was calibrated several times

\section{Total alkyl nitrates within the \\ Sacramento Urban Plume}

P. A. Cleary et al.

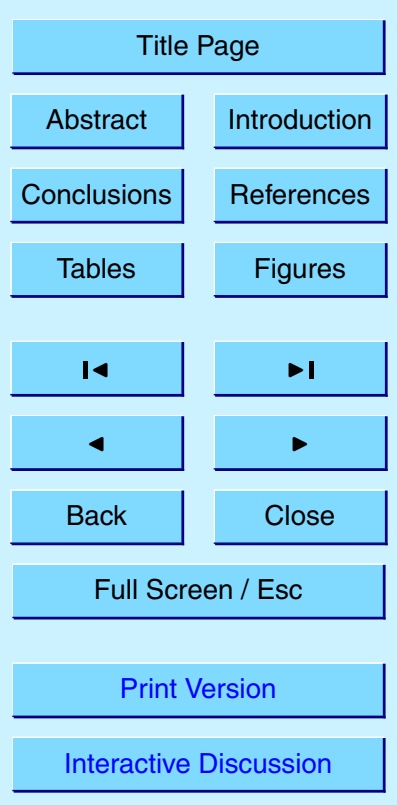

EGU 
daily by dynamic dilution (factor of 1000) of ppmv level standards (Scott Marin Inc., and Apel-Riemer Environmental Inc.) into zero air. Zero air was analyzed daily to check for blank problems and contamination for all measured compounds.

\section{Observations}

5 Measurements of $\Sigma A N s, \Sigma P N s, H_{3}, \mathrm{O}_{3}$, and temperature from 27 July-9 September 2001 are shown in Fig. 2. Over 45 VOC were measured at Granite Bay by GC-MS. These observations will be described in more detail in forthcoming manuscripts. The median mixing ratios for the morning period (09:00-12:00, local time) along with our estimates (denoted by $a{ }^{*}$, see Appendix $A$ ) of the mixing ratios of other compounds likely to contribute to the production of $O_{x}$ and $\Sigma A N s$ in the region are listed in Table 1. The average diurnal cycle of the nitrogen oxides and $O_{x}$ are shown in Fig. 3. On a daily timescale, these chemical species have patterns that closely follow solar illumination indicating rapid chemical production coupled to loss mechanisms (primarily mixing/dilution and deposition) that act on timescales of a few hours.

15 All of the observed species have variations on synoptic timescales that are correlated with large-scale transport patterns and temperature. Peak mixing ratios of $\mathrm{O}_{\mathrm{x}}$ are typical of the region (CARB, 1999). $24 \mathrm{~h}$ average values of $\mathrm{NO}_{\mathrm{x}}$ and $\mathrm{NO}_{\mathrm{y}}$ at Granite Bay were 6 ppbv and 9 ppbv respectively. Mixing ratios of $\mathrm{NO}_{\mathrm{x}}$ reported by the CARB at several nearby regional air quality monitoring sites have mean daily averages of $10-15 \mathrm{ppbv}$. The higher values at the CARB sites suggest that their $\mathrm{NO}_{\mathrm{x}}$ observations by catalysis-chemiluminescence include a large fraction of $\mathrm{NO}_{\mathrm{z}}$ $\left(\mathrm{NO}_{\mathrm{z}}=\Sigma \mathrm{PNs}+\Sigma \mathrm{ANs}+\mathrm{HNO}_{3}+\mathrm{HONO}+\ldots\right)$, as has been reported in previous studies (Kolb et al., 2004; Navas et al., 1997). It is also possible that the CARB measurements have a substantial high bias due to being located near major traffic corridors. The $\Sigma P N$ concentrations measured at Granite Bay exhibit a diurnal maximum of $1.2 \mathrm{ppbv}$ at noon and with a mean of $0.68 \mathrm{ppbv}$ during the entire study. Grosjean (2003) reviews PAN and PPN measurements made in southern California during the past 40 years. The

\section{Total alkyl nitrates within the \\ Sacramento Urban Plume}

P. A. Cleary et al.

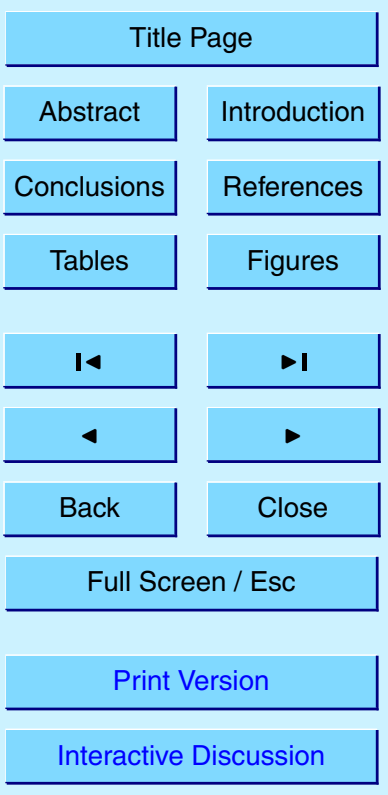

EGU 
most recent studies report PAN mixing ratios within $40 \%$ of our $\Sigma$ PN measurements at Granite Bay. The mixing ratios observed at Granite Bay are also similar to those made in other US cities. For example, Roberts et al. (2002) report that the sum of PAN, PPN and MPAN, observed outside of Nashville in June 1999, had an average daytime mixing 5 ratio of 1.14 ppbv and they report the sum of PAN, PPN, MPAN, PiBN and APAN was on average $1.18 \mathrm{ppbv}$ at La Porte, Texas during August-September 2000 (Roberts et al., 2002, 2001). Our measurements of $\mathrm{HNO}_{3}$ at Granite Bay with daytime peaks near $6 \mathrm{ppbv}$ and daily averages of $2 \mathrm{ppbv}$ are similar to the few prior urban measurements of $\mathrm{HNO}_{3}$. Bari et al observed gaseous $\mathrm{HNO}_{3}$ in Manhattan in abundances ranging from 10 1-5 ppbv (Bari et al., 2003). Neuman et al. (2002) measured $\mathrm{HNO}_{3}$ from an aircraft near La Porte, TX in the range of 4-7 ppbv. TD-LIF measurements of $\mathrm{HNO}_{3}$ on the ground at La Porte, TX peaked at 5 ppbv and averaged 3.6 ppbv (Rosen et al., 2004), demonstrating that the semi-volatile aerosol nitrate component of this measurement in a highly polluted urban environment is likely to be a small addition to the gas-phase $15 \mathrm{HNO}_{3}$.

In contrast to the $\mathrm{NO}_{2}$ and $\Sigma \mathrm{PN}$ measurements which are similar to prior measurements, the observations of $\Sigma A N$ s are considerably larger than previous measurements of any individual alkyl nitrate or of the sum of individual alkyl nitrates (Fischer et al., 2000; Grossenbacher et al., 2001; Kastler et al., 2000; O'Brien et al., 1995, 1997; Ostling et al., 2001; Roberts et al., 1998). They are much larger than $\Sigma A N$ measurements at the UC-Blodgett forest, but similar to TD-LIF observations from La Porte outside of Houston, Texas (Day et al., 2003, 2002; Rosen et al., 2004). The ratios of $\Sigma$ ANs to $\mathrm{NO}_{\mathrm{y}}(5-10 \%)$ or to $\mathrm{NO}_{\mathrm{z}}(15-25 \%)$ are also larger than nearly all prior observations of the sums of individual nitrates but comparable to our measurements of $\Sigma$ ANs
ACPD

5, 4801-4843, 2005

Total alkyl nitrates within the

Sacramento Urban Plume

P. A. Cleary et al.

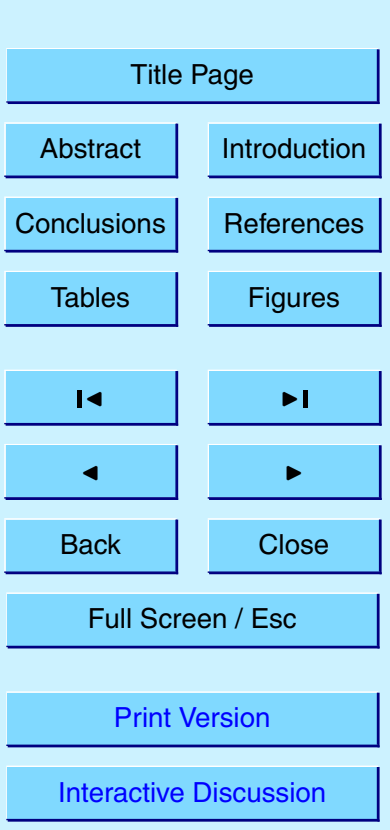




\section{Total alkyl nitrates}

The chemical mechanism responsible for producing ozone and alkyl nitrates (Fig. 4) is as follows: ozone production is initiated by oxidation of VOC (Reactions R1-2):

$\mathrm{R}-\mathrm{H}+\mathrm{OH}+\mathrm{O}_{2}+\mathrm{M} \rightarrow \mathrm{RO}_{2}+\mathrm{H}_{2} \mathrm{O}+\mathrm{M}$

$5 \quad \mathrm{R}_{1}-\mathrm{C}=\mathrm{C}-\mathrm{R}_{2}+\mathrm{OH}+\mathrm{O}_{2} \rightarrow \mathrm{R}_{1}-\mathrm{C}(\mathrm{OH})-\mathrm{C}\left(\mathrm{O}_{2}\right)-\mathrm{R}_{2}$

The peroxy radical products of Reactions (R1) and (R2) (both will be denoted $\mathrm{RO}_{2}$ ) then reacts with $\mathrm{NO}$ to form $\mathrm{NO}_{2}$ and the alkoxy radical $(\mathrm{RO})$ :

$\mathrm{RO}_{2}+\mathrm{NO} \rightarrow \mathrm{RO}+\mathrm{NO}_{2}$

Typically, the alkoxy radical reacts with $\mathrm{O}_{2}$ to form a peroxy-radical, $\mathrm{HO}_{2}$, and a carbonyl 10 compound:

$\mathrm{RO}+\mathrm{O}_{2} \rightarrow \mathrm{HO}_{2}+$ carbonyl

The $\mathrm{HO}_{2}$ reacts with $\mathrm{NO}$ to form a second $\mathrm{NO}_{2}$ and regenerates $\mathrm{OH}$ :

$\mathrm{HO}_{2}+\mathrm{NO} \rightarrow \mathrm{OH}+\mathrm{NO}_{2}$

Ozone is produced by the photolysis of $\mathrm{NO}_{2}$, and recombination of $\mathrm{O}\left({ }^{3} \mathrm{P}\right)$ with $\mathrm{O}_{2}$ :

$15 \mathrm{NO}_{2}+\mathrm{hv} \rightarrow \mathrm{O}\left({ }^{3} \mathrm{P}\right)+\mathrm{NO}$

$\mathrm{O}\left({ }^{3} \mathrm{P}\right)+\mathrm{O}_{2} \rightarrow \mathrm{O}_{3}$

Reaction (3) also proceeds along an alternate path, an association reaction producing alkyl nitrates (Reaction R3b), and terminating catalytic ozone production:

$\mathrm{RO}_{2}+\mathrm{NO} \rightarrow \mathrm{RONO}_{2}$

20 Thus for this typical oxidation path, either one alkyl nitrate is generated or 2 molecules of ozone are generated for each VOC oxidized. The branching ratio to alkyl nitrate 4810
ACPD

$5,4801-4843,2005$

Total alkyl nitrates within the

\section{Sacramento Urban}

Plume

P. A. Cleary et al.

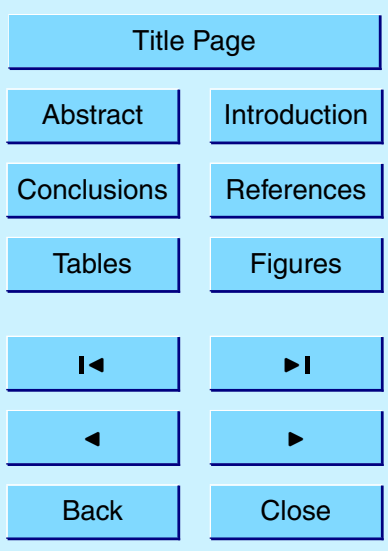

Full Screen / Esc

Print Version

Interactive Discussion 
formation is $\alpha=k_{3 b} /\left(k_{3 a}+k_{3 b}\right)$. Since the ozone production and total alkyl nitrate ( $\left.\Sigma A N\right)$

The reaction sequence outlined above is initiated by Reactions (R1) or (R2) and 5 proceeds almost quantitatively, thus the instantaneous ozone production rate in an air parcel is given by:

$\mathrm{P}_{\mathrm{O}_{3}}=\sum_{i} \gamma_{i}\left(1-\alpha_{i}\right) k_{\mathrm{OH}+V O C_{i}}[\mathrm{OH}]\left[V O C_{i}\right]$

and the $\Sigma$ AN production rate by:

$$
P_{\text {IANS }}=\sum_{i} \alpha_{i} k_{\mathrm{OH}+V O C_{i}}[\mathrm{OH}]\left[V O C_{i}\right]
$$

10 where $\gamma_{i}$ is the number of peroxy radicals produced in the $\mathrm{HO}_{\mathrm{x}}$ cycle from $\mathrm{VOC}_{i}, \mathrm{k}_{i}$ is the rate coefficient for the reaction of $\mathrm{VOC}_{i}$ with $\mathrm{OH}$, and $\alpha_{i}$ is the alkyl nitrate branching ratio for the $\mathrm{R}_{i} \mathrm{O}_{2}+\mathrm{NO}$ reaction. As shown in Fig. $4, \gamma$ is typically 2 , although it is 1 for direct sources of $\mathrm{HO}_{2}$ such as the reactions of $\mathrm{OH}$ with $\mathrm{CO}$ or $\mathrm{H}_{2} \mathrm{CO}$ and larger than 2 for VOC whose initial $\mathrm{RO}_{2}$ fragments produce a second $\mathrm{RO}_{2}$ prior to $\mathrm{HO}_{2}$ such as $\mathrm{n}$ 15 butane (Atkinson, 1997). $\mathrm{HO}_{\mathrm{x}}-\mathrm{HO}_{\mathrm{x}}$ chain termination reactions, such as $\mathrm{HO}_{2}+\mathrm{HO}_{2}$ or $\mathrm{HO}_{2}+\mathrm{RO}_{2}$ also reduce $\gamma$ and $\Sigma \mathrm{AN}$ formation. However, these effects are minor under high $\mathrm{NO}_{\mathrm{x}}$ conditions such as were present in this data set, modifying the effective $\gamma$ for the production rate of $\Sigma$ ANs for the ambient VOC mixture by less than $10 \%$. We neglect them in this analysis. Table 1 lists the constants needed to evaluate Eqs. (2) and (3). The branching ratios to nitrate formation are estimated by analogy to similar compounds where laboratory measurements are unavailable.

To a first approximation, the composition of $\Sigma A N s$ in the atmosphere should closely reflect their source distribution in the morning (Rosen et al., 2004). The sources at Granite Bay are detailed in Table 1 and summarized by category in Table 2. Scaling the observed $\Sigma A N s$ by the relative contribution of the individual sources, the morning (09:00-12:00 LT) $\Sigma A N$ mixing ratio averaging 700 pptv corresponds to mixing ratios of

\section{Total alkyl nitrates within the Sacramento Urban Plume}

P. A. Cleary et al.

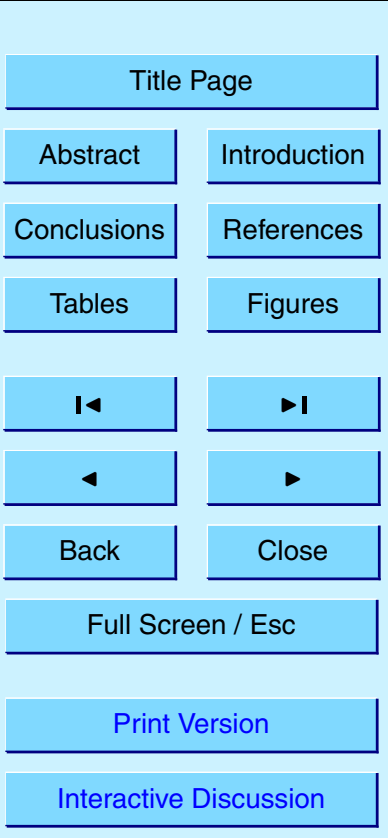

EGU 
$190 \mathrm{pptv}$ of isoprene nitrates, $140 \mathrm{pptv}$ of aldehyde nitrates, $96 \mathrm{pptv}$ of terpene nitrates, 71 pptv of hydroxyalkyl nitrates derived from alkenes, alkynes or aromatics and 72 pptv of multifunctional nitrates derived from isoprene oxidation products. Dinitrates formed by the $\mathrm{OH}$ reactions with alkyl nitrates are estimated to be $35 \mathrm{pptv}$. The sum of $\mathrm{C}_{1}$ $5 \mathrm{C}_{9}$ alkyl nitrates corresponding to the alkane precursors in Table 1 is estimated to be 56 pptv. Only $8 \%$ of the nitrates are calculated to be monofunctional species.

Shepson and coworkers have given the most attention to multifunctional nitrates. Direct measurements of isoprene nitrates by Grossenbacher et al during the PROPHET 1998 campaign in northern Michigan ranged from 0.5-35 pptv (Grossenbacher et al., 10 2001). During SOS 1999 experiments in central Tennessee, Grossenbacher measured 115 pptv of isoprene nitrates at midday. At the PROPHET site, low concentrations of isoprene nitrates were attributed by Grossenbacher et al to the combined effects of the close proximity to isoprene sources and to the large fraction of isoprene peroxy radicals removed by reactions with other peroxy radicals (Grossenbacher et al., 2004). Our es-

timate of 190 pptv averaged from 09:00-12:00 h, and 270 pptv at noon are larger than the observations by Grossenbacher. However, the difference is likely due in part to the short lifetime of isoprene nitrates before conversion to different nitrate species, which are indistinguishable from the parent nitrates in the $\Sigma A N$ measurements but would not be identified as an isoprene nitrate in experiments measuring a specific compound. O'Brien et al. (1997) report the sum of 17 different $C_{3}-C_{6}$ alkyl nitrates and $C_{2}-C_{4}$ hydroxy-alkyl nitrates (not including isoprene nitrates), which ranged from 50-550 pptv in the lower Fraser Valley, British Columbia. O'Brien et al. (1995) measured the same 17 species of alkyl and hydroxy-alkyl nitrates and report a sum that ranged from 12140 pptv at a rural site in Ontario. We scale the measured $\Sigma A N s$ by the relative rates of production from the VOC precursors to estimate that the sum of $\mathrm{C}_{3}-\mathrm{C}_{6}$ alkyl and $\mathrm{C}_{2}$ $\mathrm{C}_{4}$ hydroxy-alkyl nitrates are $6 \%$ of $\Sigma$ ANs ( 40 pptv at 09:00-12:00 h) at Granite Bay. The other major efforts on multifunctional nitrates are from Ballschmiter and colleagues (Fischer et al., 2002, 2000; Kastler et al., 2000; Luxenhofer et al., 1996; Werner et al., 1999), who measured the sum of $\mathrm{C}_{6}-\mathrm{C}_{10}$ alkyl mononitrates in the range 2.9-11 pptv
ACPD

$5,4801-4843,2005$

Total alkyl nitrates within the

Sacramento Urban Plume

P. A. Cleary et al.

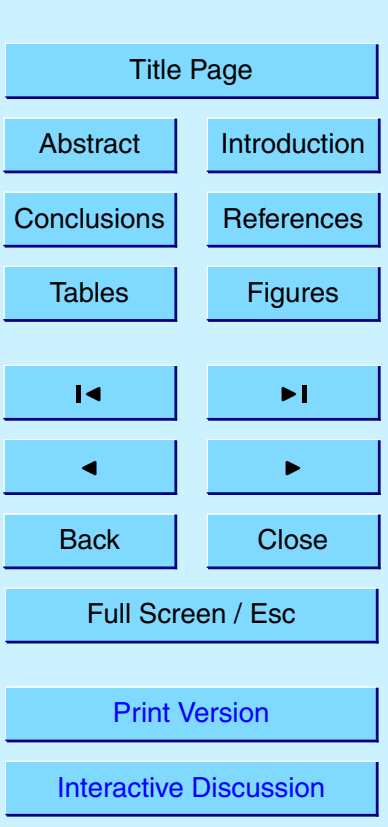


and the sum of $\mathrm{C}_{2}-\mathrm{C}_{4}$ hydroxy-alkyl nitrates in the range 7.3-28 pptv in urban smog at several sites. At Granite Bay we estimate these same compounds $\left(C_{6}-C_{10}\right.$ alkyl $\pm C_{2}-C_{4}$ hydroxy-alkyl) nitrates total 30 pptv in the morning.

There are many more studies of the monofunctional nitrates. For example, Flocke 5 et al. (1998) describe measurements of $C_{1}-C_{8}$ alkyl nitrates ranging from 30-620 pptv at a site in southern Germany (Flocke et al., 1998). Scaling our $\Sigma A N$ observations to the production rate from the VOC precursors gives an estimate of $56 \mathrm{pptv}$ for these species at Granite Bay. Ostling et al. (2001) report summertime $C_{3}-C_{5}$ alkyl nitrate measurements at the PROPHET site in northern Michigan that range from 3-66 pptv 10 and average 18.6 pptv; our scaled observations for these species are 29 pptv at 09:0012:00 and 25 pptv averaged over the entire campaign.

To summarize, the results presented in this section show that partitioning the observed $\Sigma$ ANs in proportion to their sources results in estimates of the mixing ratio of individual organic nitrates that are in the range of prior observations.

\section{Correlations of $\Sigma$ ANs with ozone}

The correlation of $\mathrm{O}_{x}$ with $\Sigma$ ANs is shown in Fig. 5. All of the observations are shown as open circles with those between 09:00 and 12:00 $\mathrm{h}$ local time shown filled with black and between 14:00 and 18:00 $\mathrm{h}$ local time filled with grey. The measured concentrations of $O_{x}$ and of $\Sigma A N s$ at the surface and their correlation are not only affected by production, but also by deposition, by entrainment of air from the surroundings and by chemical losses. Changes in the ratio of $\mathrm{O}_{\mathrm{x}}$ to $\Sigma \mathrm{ANN}$ over time are thus represented by Eq. (4):

$$
\frac{\Delta \mathrm{O}_{\mathrm{x}}}{\Delta \Sigma A N s}=\frac{\int\left(P_{\mathrm{O}_{\mathrm{x}}}-D_{\mathrm{O}_{\mathrm{x}}}+E_{\mathrm{O}_{\mathrm{x}}}-L_{\mathrm{O}_{\mathrm{x}}}\right) d t}{\int\left(P_{\Sigma A N s}-D_{\Sigma A N s}+E_{\Sigma A N s}-L_{\Sigma A N s}\right) d t}
$$

where $P$ represents the chemical production, $D$ the deposition, $E$ the entrainment and

$L$ the chemical losses for each species. As illustrated by Rosen et al. (2004), if the

ACPD

$5,4801-4843,2005$

Total alkyl nitrates within the

Sacramento Urban Plume

P. A. Cleary et al.

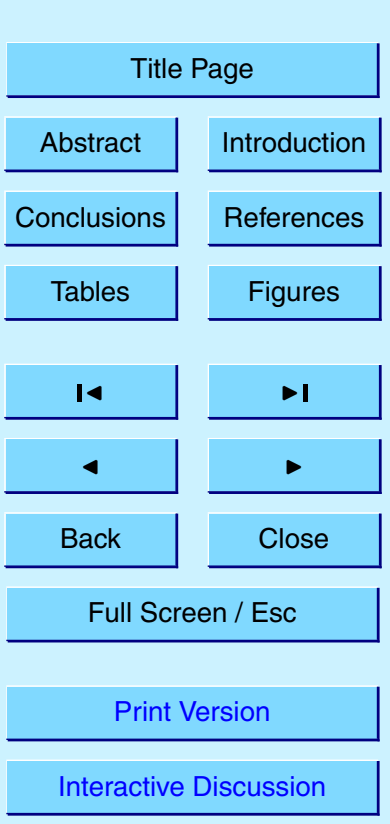

EGU 
VOC mix that produces $\mathrm{O}_{\mathrm{x}}$ and $\Sigma \mathrm{ANs}$ does not vary significantly with time and both deposition and entrainment rates are negligible, the correlation of $\mathrm{O}_{\mathrm{x}}$ and $\Sigma \mathrm{ANs}$ will be linear (the applicability of these assumptions will be examined below). When this is the case, the slope, $\Delta \mathrm{O}_{x} / \Delta \Sigma \mathrm{ANs}$, is then represented by the ratio of Eqs. (2) and (3) 5 evaluated with the VOC mix from a single point in time which is equivalent to Eq. (5):

$$
\frac{\Delta \mathrm{O}_{\mathrm{x}}}{\Delta \Sigma A N S} \approx \frac{P_{\mathrm{O}_{\mathrm{x}}}}{P_{\Sigma A N S}} \approx \frac{2(1-A)}{A} \approx \frac{2}{A}
$$

where the constant A is the alkyl nitrate yield for the VOC mixture. Rosen et al. (2004) show that in the absence of mixing, observations early in the daily oxidation sequence should have an $\mathrm{O}_{\mathrm{x}}-\Sigma \mathrm{AN}$ relationship that closely approximates that of the primary VOC $\mathrm{mix}$ in the region. In contrast, if deposition of $\Sigma A N s$ or changes in the VOC mixture that increase the rate of ozone production without increasing the rate of $\Sigma A N$ production occurs, then the correlation will exhibit significant curvature.

Rosen et al. show that if observations are restricted to early in the day these effects are minimized and a linear correlation will still be observed. However, this analysis by 15 Rosen et al. also made the implicit assumption that the initial values for $\mathrm{O}_{\mathrm{x}}$ and $\Sigma$ ANs each day are nearly identical so that increases in the mixing ratios of $O_{x}$ and $\Sigma A N s$ represent a vector originating at a single point on the correlation diagram, a situation that was true for the data set from La Porte, TX described by Rosen et al. (2004), but is not the case for the Granite Bay data set where we observe a large and highly variable mixing ratio of $\Sigma A N s$ in the early morning. As a result the correlation plot for data at Granite Bay is to some extent skewed by these initial conditions.

At Granite Bay, the slope of the observed correlation of $O_{x}$ versus $\Sigma A N s$ in the morning (9:00-12:00 local time) is $34.6( \pm 0.9,1 \sigma)$ (reduced major axis fitting, $\left.R^{2}=0.44\right)$ (black symbols Fig. 5), corresponding to an alkyl nitrate yield, A, of $5.8( \pm 0.2) \%$. The 25 slope for data from the afternoon at Granite Bay (14:00-18:00 LT) is $49.2( \pm 1.2)$ (grey symbols Fig. 5) corresponding to a yield of $4.0( \pm 0.1) \%$. The slope derived from observations in the afternoon are higher than in the morning likely due the increasing

ACPD

$5,4801-4843,2005$

Total alkyl nitrates within the

Sacramento Urban Plume

P. A. Cleary et al.

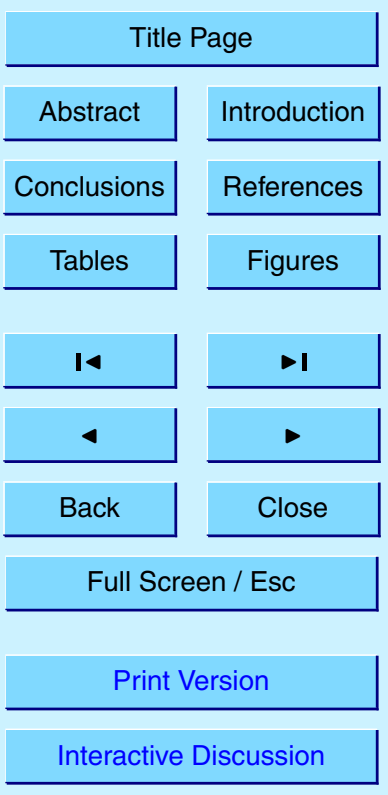

EGU 
importance of formaldehyde and other secondary organics with high ozone yields and near zero nitrate yields and possibly also to more rapid deposition of hydroxyalkyl nitrates than $\mathrm{O}_{\mathrm{x}}$. If instead of directly fitting the slope of the observed correlation plot we first subtract the median $\mathrm{O}_{\mathrm{x}}$ and $\Sigma$ ANs observed in the hour surrounding 08:00 $\mathrm{h}$ 5 we arrive at the representation of the data shown in Fig. 6. The figure includes data from $10: 30 \mathrm{~h}$ to $12: 00 \mathrm{~h}$ to allow enough time for chemical production to significantly increase the $\mathrm{O}_{\mathrm{x}}$ and $\Sigma A N s$ above their 08:00 $\mathrm{h}$ value. Since each point in this figure represents $\Delta \mathrm{O}_{\mathrm{x}} / \Delta \Sigma \mathrm{ANs}$ at different times, the variation in the data represents changes in that slope for different times of day, or for different production rates observed on dif10 ferent days. Figure 6 provides evidence for a range of different slopes, some of which do overlap with the slope inferred from Fig. 5. A fit to the data of Fig. 6 gives a slope of $48.1( \pm 2.3) \Delta \mathrm{O}_{x} / \Delta \Sigma \mathrm{ANs}$, corresponding to a $\Sigma$ AN yield of $4.2 \%( \pm 0.2)$. In our opinion the $4.2 \%$ yield inferred from the fit to Fig. 6 is our most reliable estimate of the typical value of the yield at this site although one could make a reasonable argument for slopes as high as 65 using Fig. 5 as low as 29 using the median value of the data shown in Fig. 6. The large values of $\Sigma A N s$ observed at night at Granite Bay strongly influence the slope derived from the raw correlation of daytime measurements of $O_{x}$ and $\Sigma$ ANs (Fig. 5). This large background obscures the effects of photochemistry on any given day. This is in contrast to observations reported by Rosen et al. (2004) where the nighttime $\Sigma A N s$ were typically less than $0.2 \mathrm{ppb}$; subtracting an initial value for $\mathrm{O}_{\mathrm{x}}$ and $\Sigma$ ANs for each day of that data set has no effect on the correlation slope.

Although the slope of 48 is derived from a fit to the data in Fig. 6, the data shown do include events corresponding to slopes as low as 30 and with ozone increases at the same time as $\Sigma$ AN decreases. The latter events are most likely dominated by mixing and not by local photochemical production. The variance in the observed correlation is partly due to variation in meteorology as illustrated by Fig. 7, which shows observations from typical and atypical meteorological episodes 29 July 2001 (Fig. 7a), is representative of most of the days of the campaign where the winds shifted to $200^{\circ}$ (from Sacramento) by late morning. $O_{x}$ is 40 ppbv at 08:00 LT, 75 ppbv at noon and
ACPD

$5,4801-4843,2005$

\section{Total alkyl nitrates within the Sacramento Urban Plume}

P. A. Cleary et al.

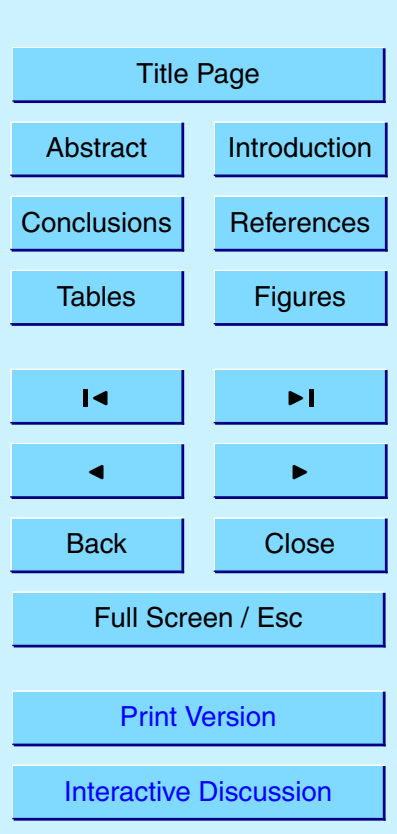


rises to above $100 \mathrm{ppbv}$ in the late afternoon and $\Sigma A N s$ are $0.45 \mathrm{ppbv}$ at $08: 00 \mathrm{~h}$ rising to $1.3 \mathrm{ppbv}$ at noon. The difference between the morning and noontime values gives $\Delta \mathrm{O}_{\mathrm{x}} / \Delta \Sigma \mathrm{ANs}$ equal to 35 . In contrast, on 31 July (Fig. $7 \mathrm{~b}$ ), the winds turn very slowly and were not arriving from the direction of Sacramento $\left(200^{\circ}\right)$ until the late afternoon. $5 \mathrm{O}_{\mathrm{x}}$ peaked at $40 \mathrm{ppbv}$ and $\Sigma$ ANs did not increase on this day. On 7 September (Fig. 7c), the wind direction swings from the east at $45^{\circ}$ to due west at $275^{\circ}$ at 06:00 h. Air arriving at Granite Bay directly from the west is not from urban Sacramento, but rather the rural region to the north of the city. The $\Sigma A N s$ are unusually high $(1.2 \mathrm{ppb})$ even before sunrise that morning, suggesting that production by $\mathrm{NO}_{3}$ chemistry during the night 10 might have been important. $\Sigma$ ANs then decrease for most of the day rising again only when the winds change direction late in the afternoon altering the source region for those observations.

In addition to, or perhaps coupled with, meteorological variability, there is photochemical variability in the VOC sources that drive the $O_{x} / \Sigma A N s$ correlation. On some days, we observe a high ratio of isoprene oxidation products to the parent compound at 09:00 LT suggesting there has already been significant oxidation of reactive VOC. As a result, we expect high concentrations of secondary photoproducts, such as $\mathrm{H}_{2} \mathrm{CO}$, a compound that contributes to $\mathrm{O}_{\mathrm{x}}$ production but not $\Sigma \mathrm{AN}$ production. Variation in the contribution of early morning oxidation is an effect that biases the spread of the $\mathrm{O}_{\mathrm{x}} / \Sigma$ ANs correlation to higher slopes (lower yields) than the slope representing the primary VOC mixture. If this was the main source of bias, then it is likely that the slope derived from Figs. 5 and 6 are not representative of the primary VOC mixture and that the $\Sigma$ AN yield of that mixture might be higher than the $4.2-5.8 \%$ inferred from those figures.

\section{Calculating the $\Sigma \mathrm{AN}$ yield}

Direct calculation of the $\Sigma A N$ yield for the VOC mixture at the site shows that the estimate of $4.2-5.8 \%$ for the $\Sigma A N$ yield derived from correlations with $\mathrm{O}_{x}$ above is
ACPD

$5,4801-4843,2005$

\section{Total alkyl nitrates within the \\ Sacramento Urban Plume}

P. A. Cleary et al.

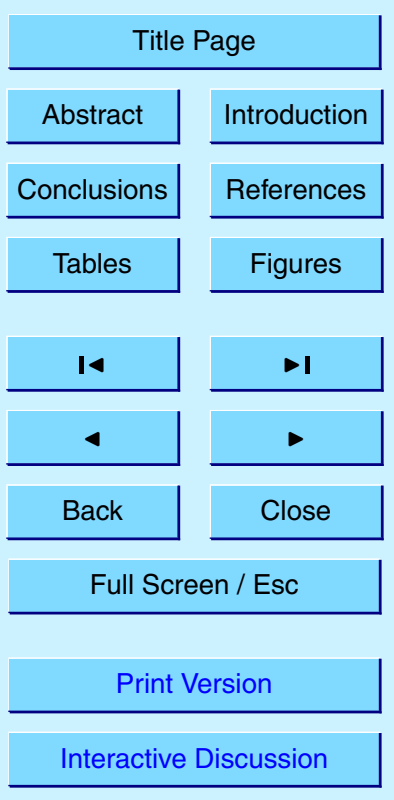

EGU 
reasonable. $\mathrm{P}_{\mathrm{Ox}}$ and $\mathrm{P}_{\Sigma A N s}$ at Granite Bay are calculated for each individual VOC (Table 1) using an assumed mean $\mathrm{OH}$ concentration of $5 \times 10^{6}$ molecules $\mathrm{cm}^{-3}$ from 09:00-12:00 LT (Cleary, 2003; Dillon et al., 2002a; Dreyfus et al., 2002; Schade and Goldstein, 2001). Note the absolute $\mathrm{OH}$ concentration is important to calculating the 5 rate of increase in $\mathrm{O}_{x}$ or $\Sigma$ ANs as we do below, but is unimportant to a calculation of the slope of $O_{x}$ vs. $\Sigma$ ANs because daytime chemical production of both of these species are proportional to $\mathrm{OH}$. Table 2 summarizes the contributions for each of the major categories of compounds as well as a few individual compounds. The major sources of ozone are isoprene (22.4\%), $\mathrm{C}_{2}$ and larger aldehydes $(20.8 \%)$, isoprene 10 oxidation products (12.5\%) and formaldehyde (12.3\%). The major sources of $\Sigma$ ANs are biogenic compounds which are together responsible for $50 \%$ of the $\Sigma$ ANs including isoprene $(27 \%)$ and its oxidation products $(10 \%)$ and terpenes and their oxidation products (14\%). There is also a large contribution from the higher aldehydes $(20 \%)$, the largest portion of which comes from nitrates derived from nonanal $(75 \%$ of aldehyde 15 nitrates, $15 \%$ of total alkyl nitrates). Using this data and Eqs. (10)-(12), we calculate the slope of $\Delta \mathrm{O}_{3} / \Delta \Sigma$ ANs to be 52 and an alkyl nitrate yield, $\mathrm{A}$, of $3.7 \%$, for the VOC mixture at Granite Bay. This yield is similar to the $4.2 \%$ yield that is our best estimate derived from Fig. 6.

Notable uncertainties in the calculated yield are 1) completeness of the observed and estimated VOC mixture and 2) uncertainty about the nitrate yield of individual molecules. With respect to the first item, recent evidence suggests that there may be considerable emissions of sesquiterpenes and other highly reactive species that are not represented in current inventories or in our estimates (Di Carlo et al., 2004; Goldstein et al., 2004). Little is known about the net source of $O_{x}$ or $\Sigma A N s$ these species 25 represent. With respect to the second item, the isoprene nitrate yield has been reported at values ranging from 4.4 to $15 \%$ (Chen et al., 1998; Chuong and Stevens, 2002; Sprengnether et al., 2002; Tuazon and Atkinson, 1990). As isoprene represents $26.7 \%$ of the calculated $\Sigma A N$ source this is a major uncertainty. Our calculation of a $3.7 \%$ effective yield for the VOC mixture at Granite Bay used the lowest end of this

ACPD

$5,4801-4843,2005$

\section{Total alkyl nitrates within the \\ Sacramento Urban Plume}

P. A. Cleary et al.

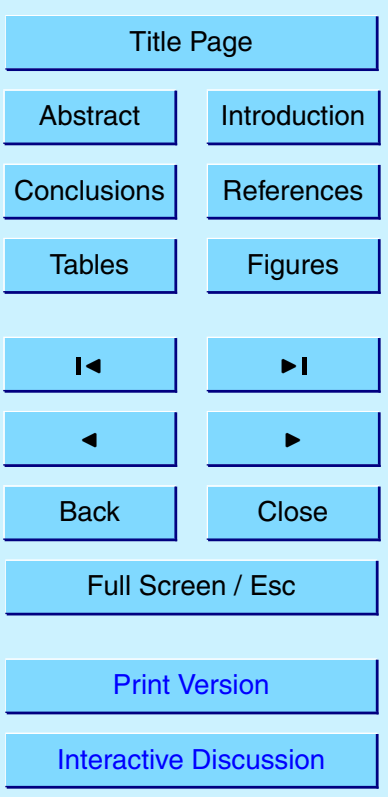

EGU 
range, because the branching ratio was determined from direct measurements of all isoprene nitrate isomers. If instead we use $12 \%$, a number near the high end of the range, we find that isoprene nitrates represent $50 \%$ of the nitrate source and the total yield increases to $5.7 \%$. This is at the high end of what might be compatible with the 5 observations. The uncertainty in the isoprene nitrate yield is by far the largest quantifiable uncertainty in our understanding of $\Sigma A N$ yields. However, there are other important terms to the overall yield such as the nitrate yields of isoprene oxidation products and the mixing ratio of formaldehyde that are also quite uncertain. The sensitivity of the calculated yield to these terms is much lower than the sensitivity to the isoprene nitrate 10 yield but still significant. For example, doubling ( $8 \mathrm{ppbv})$ or halving ( $2 \mathrm{ppbv})$ the mixing ratio of formaldehyde results in calculations of the $\Sigma$ AN yields for the VOC mixture of $3.4 \%$ and $4.1 \%$, respectively. Halving or doubling the nitrate yields of isoprene oxidation products puts the calculated yields in the range $3.6 \%$ to $4.3 \%$. In combination, an isoprene nitrate yield of $12 \%$ and an $\mathrm{H}_{2} \mathrm{CO}$ mixing ratio of $2 \mathrm{ppb}$ results in a $\Sigma$ AN yield

of $6.1 \%$. Direct calculation of $\mathrm{P}\left(\mathrm{O}_{\mathrm{x}}\right)$ and $\mathrm{P}(\Sigma \mathrm{ANs})$ for the $\mathrm{VOC}$ mixture at this site thus gives a $\Sigma$ AN yield of $3.4-6.1 \%$ with a best estimate of $3.7 \%$. This is consistent with the range calculated from the observed $\mathrm{O}_{\mathrm{x}} / \Sigma \mathrm{AN}$ correlation $(4.2-5.8 \%$, best estimate of $4.2 \%)$.

\section{The morning tise of $\Sigma$ ANs and ozone}

20 Although the analyses above lend support to the interpretation of the rise in $\Sigma A N s$ as implying a $4.2 \%$ yield of $\Sigma$ ANs during the oxidation of the VOCs at this site, it has the weakness that it neglects entrainment, deposition and chemical losses. In this section we present a more quantitative investigation of the effects of these factors on $\Sigma$ ANs and $\mathrm{O}_{\mathrm{x}}$ by adapting a simple Lagrangian model described by Dillon et al. (2002a) to

We use a model that represents production and entrainment to calculate the simultaneous increases in $\mathrm{O}_{x}$ and $\Sigma A N s$. The model assumes chemical evolution of a plume

ACPD

$5,4801-4843,2005$

Total alkyl nitrates within the

Sacramento Urban Plume

P. A. Cleary et al.

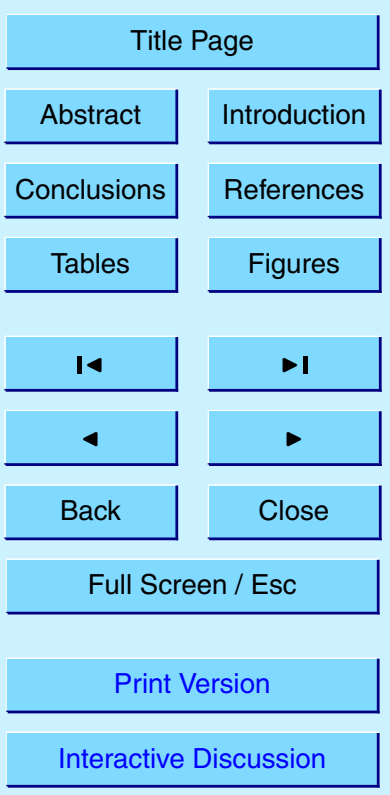

EGU 
with $\mathrm{O}_{\mathrm{x}}$ and $\Sigma A N$ production rates $\left(\mathrm{P}_{\mathrm{Ox}}\right.$ and $\left.\mathrm{P}_{\Sigma A N S}\right)$ initialized at the time, $\mathrm{t}$, as it mixes with a background atmosphere with values of $\left[\mathrm{O}_{\mathrm{x}}\right]_{b}$ and $[\Sigma \mathrm{ANs}]_{b}$ as governed by a dilution time constant $(\mathrm{K})$. This model has 5 parameters: $\mathrm{K}, \mathrm{P}_{\Sigma A N s}, \mathrm{P}_{\mathrm{Ox}},\left[\mathrm{O}_{\mathrm{x}}\right]_{b}$ and $[\Sigma \mathrm{ANs}]_{b}$ :

${ }_{5} \frac{d\left[\mathrm{O}_{\mathrm{x}}\right]}{d t}=-K\left(\left[\mathrm{O}_{\mathrm{x}}\right]-\left[\mathrm{O}_{\mathrm{x}}\right]_{b}\right)+P_{\mathrm{O}_{\mathrm{x}}}$

$$
\frac{d[\Sigma A N s]}{d t}=-K\left([\Sigma A N s]-[\Sigma A N s]_{b}\right)+P_{\Sigma A N s}
$$

Both the chemical losses and the deposition described in equation 5 can be neglected. In the morning we estimate a boundary layer height of $500 \mathrm{~m}$ near Granite Bay. Assuming a deposition velocity of $0.5 \mathrm{~cm}-\mathrm{s}^{-1}$ the removal of $\mathrm{O}_{\mathrm{x}}$ and $\Sigma \mathrm{ANs}$ by deposition 10 is about $3.5 \%-h^{-1}$. An estimate of the chemical losses of $O_{x}$ is $2 \%-h^{-1}$ and we assume reactions of specific $\Sigma A N$ s largely convert those species to other $\Sigma$ ANs for net zero chemical loss of the sum. These terms are roughly a factor of 10 smaller than the chemical production or entrainment rates.

Dillon et al. (2002a) used a model of this form to derive mixing rates and the $\mathrm{OH}$ concentration as they affect VOC during afternoon transport of the Sacramento regional plume from the city into the foothills of the Sierra Nevada. That analysis derived a value for $\mathrm{K}$ of $0.23 \mathrm{~h}^{-1}$ and an $\mathrm{OH}$ concentration of $1.4 \times 10^{7}$ molecules $\mathrm{cm}^{-3}$ as an average representing the 5 afternoon hours downwind of the Sacramento suburbs during July 1997. In that region, $\mathrm{NO}_{\mathrm{x}}$ concentrations are decreasing from their peak near Granite 20 Bay. We adopt a lower value of $\mathrm{OH}$ of $5 \times 10^{6}$ molecules $-\mathrm{cm}^{-3}$ to reflect the fact that $\mathrm{OH}$ is lower in the morning than at midday and to account for suppression of $\mathrm{OH}$ by high $\mathrm{NO}_{\mathrm{x}}$ conditions along the trajectories arriving at Granite Bay. The $\mathrm{OH}$ we use is also consistent with the observed $\Sigma \mathrm{PNs} / \mathrm{NO}_{2}$ ratio at Granite Bay (Cleary et al., $2005^{1}$ ) and

\footnotetext{
${ }^{1}$ Cleary, P. A., Wooldridge, P. J., Millet, D., Goldstein, A. H., and Cohen, R. C.: On the photostationary state of PANs, Aldehydes, $\mathrm{NO}_{x}$ and $\mathrm{OH}, \mathrm{J}$. Geophys. Res., in preparation, 2005.
}

ACPD

$5,4801-4843,2005$

\section{Total alkyl nitrates within the \\ Sacramento Urban Plume}

P. A. Cleary et al.

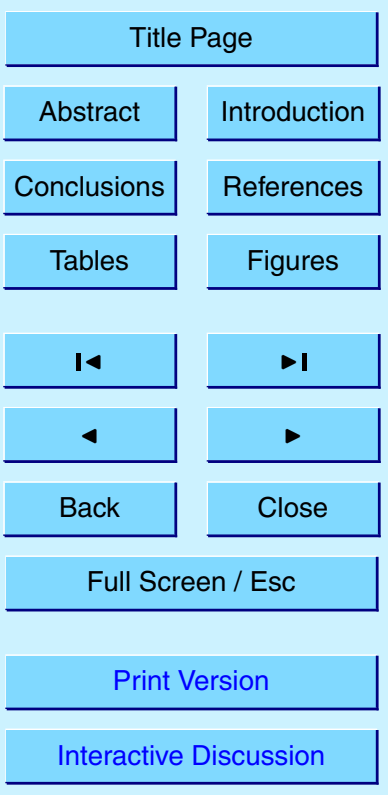

EGU 
with the $\mathrm{HNO}_{3} / \mathrm{NO}_{2}$ ratios at Granite bay (J. Murphy, personal communication).

With an average $\mathrm{OH}$ concentration of $5 \times 10^{6}$ molecules $-\mathrm{cm}^{-3}$ and the VOC listed in Table 1 the calculated production rate is $12.5 \mathrm{ppbv}-\mathrm{h}^{-1}$ for $\mathrm{O}_{\mathrm{x}}$, and $0.242 \mathrm{ppbv}-\mathrm{h}^{-1}$ for $\Sigma A N s$, both numbers that are roughly double the observed rates of increase shown in 5 Fig. 7. Thus we require mixing to slow the rise in the concentrations of $O_{x}$ and $\Sigma A N s$. This implies the background we are mixing with has concentrations below those of the plume. Ozone concentrations above the boundary layer are known to be 50-60 ppb (Carroll and Dixon, 1998) thus the primary mixing affecting ozone at Granite Bay must be within the surface layer or a residual nocturnal layer that has experienced significant 10 ozone loss overnight. We set the $\mathrm{O}_{\mathrm{x}}$ background to $30 \mathrm{ppbv}$ based on the nighttime observations in the surface layer. Whereas at locations farther downwind from the Sacramento urban plume, the $\Sigma$ ANs tend to have larger nighttime and 'background' abundances (as high as $600 \mathrm{ppt}$ ) (Day et al., 2004), the events driving $\Sigma A N$ background and nighttime concentrations at this site are not well known, requiring that we use the 15 observations and model to derive it.

The model is initialized at $08: 00 \mathrm{~h}$ with $\mathrm{O}_{\mathrm{x}}$ of $32 \mathrm{ppbv}$ and $\Sigma$ ANs of $0.58 \mathrm{ppbv}$ and constrained to reproduce the median noontime values of $\mathrm{O}_{\mathrm{x}}$ and $\Sigma \mathrm{ANs}$ of $54 \mathrm{ppbv}$ and $0.99 \mathrm{ppbv}$, respectively. We examine three scenarios that illustrate the constraints on our understanding and the remaining uncertainties. In scenario 1 , we fix $\mathrm{P}_{\mathrm{Ox}}$ at 20 $12.5 \mathrm{ppbv} \mathrm{h}^{-1}, \mathrm{P}_{\Sigma A N S}$ at $0.242 \mathrm{ppbv} \mathrm{h}^{-1}$ and the background $\mathrm{O}_{\mathrm{x}}$ at $30 \mathrm{ppbv}$. We then solve for $\mathrm{K}$ and the background $\Sigma \mathrm{ANs}$ and the resulting parameters are: $\mathrm{K}=0.44$; and $[\Sigma \mathrm{ANs}]_{b}=0.53 \mathrm{ppbv}$. In this scenario the ratio of the production rates is the same as calculated from Table 1 and is within the range indicated by the data. However, this scenario requires a mixing rate almost double that inferred for the afternoon by Dillon 25 et al. (2002b) of 0.23 and the background $\Sigma$ AN mixing ratio derived is larger than observed during a typical night.

For scenario 2 , we fix $\mathrm{K}$ at the $0.23 \mathrm{~h}^{-1}$ value derived by Dillon et al. (2002), $\mathrm{P}_{\Sigma A N s}$ from Table 1 at $0.242 \mathrm{ppbv} \mathrm{h}^{-1}$ and the background of $\mathrm{O}_{\mathrm{x}}$ at $30 \mathrm{ppbv}$, and derive the

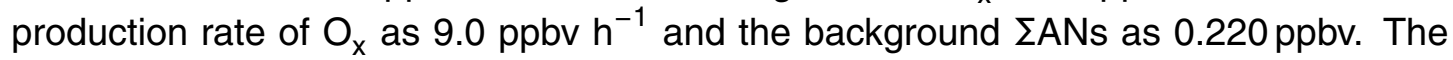

ACPD

$5,4801-4843,2005$

\section{Total alkyl nitrates within the \\ Sacramento Urban Plume}

P. A. Cleary et al.

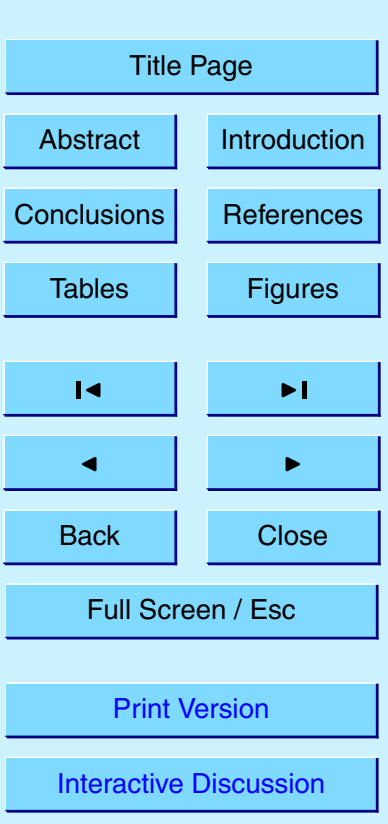

EGU 
ratio of the production rates in this scenario is 37.2 which corresponds to a $5.3 \% \Sigma A N$ yield. The background $\Sigma A N$ s derived in this scenario is about half the median nighttime value of $0.4 \mathrm{ppbv}$. The relative production rates of $\mathrm{O}_{\mathrm{x}}$ and $\Sigma$ ANs derived for this scenario could be achieved by a combination of increases in the nitrate yields for isoprene and 5 its oxidation products and decreases in $\mathrm{H}_{2} \mathrm{CO}$. The absolute rates could be achieved by reducing $\mathrm{OH}$ by $28 \%$, a change that is within the uncertainty of our estimates of $\mathrm{OH}$ although at the high end of that uncertainty. For a third scenario, we fix the background $\mathrm{O}_{\mathrm{x}}$ and $\Sigma$ ANs at their $08: 00 \mathrm{~h}$ values of $32 \mathrm{ppbv}$ and $0.58 \mathrm{ppbv}$ and fix the dilution rate at $0.23 \mathrm{~h}^{-1}$. Here we derive $\mathrm{P}_{O x}$ as $8.5 \mathrm{ppb}-\mathrm{h}^{-1}$ and $\mathrm{P}_{\Sigma A N s}$ as $0.16 \mathrm{ppbv}-\mathrm{h}^{-1}$. These 10 production rates correspond to a slope of 53 and a $\Sigma$ AN yield of $3.8 \%$ values consistent with the observations and require reducing $\mathrm{OH}$ to $66 \%$ of our estimate.

All three of these scenarios reproduce the observed rise in $\mathrm{O}_{\mathrm{x}}$ and $\Sigma$ ANs. Taken together, they suggest a range of parameters that are consistent with the observed time evolution of $\mathrm{O}_{\mathrm{x}}$ and $\Sigma \mathrm{ANs}$ at Granite Bay are: the mixing term $\mathrm{K}$ in the range 0.23 $150.43 \mathrm{~h}^{-1}, \mathrm{OH}$ in the range $3.4-5 \times 10^{6}, \mathrm{P}_{\mathrm{Ox}}$ in the range 8.5-12.5 ppbv- ${ }^{-1}, \mathrm{P}_{\Sigma A N s}$ in the range $0.16-0.242 \mathrm{ppbv}^{-1} \mathrm{~h}^{-1}$, an $\mathrm{O}_{\mathrm{x}}$ background near $30 \mathrm{ppbv}$ and a $\Sigma$ ANs background in the range $0.27-0.55 \mathrm{ppbv}$, and a corresponding AN yield in the range of 3.9-5.3.

\section{8. $\mathrm{HO}_{\mathrm{x}}$ and $\mathrm{NO}_{\mathrm{x}}$ chain termination}

One of the major reasons that $\Sigma A N$ yields are of interest is that $\Sigma A N$ formation is a termination step for both the $\mathrm{HO}_{x}$ and $\mathrm{NO}_{x}$ catalytic cycles. At low $\mathrm{NO}_{x}$ where $\mathrm{OH}$ concentrations are low, the formation rate of $\mathrm{HNO}_{3}$ slows and under conditions with high VOC reactivity, $\Sigma A N$ formation is the main termination step for the $\mathrm{NO}_{\mathrm{x}}$ catalytic cycle. Similarly, $\Sigma A N$ formation remains an important contributor to $\mathrm{HO}_{\mathrm{x}}$ chain termination at low $\mathrm{NO}_{\mathrm{x}}$ because mixing ratios of $\mathrm{RO}_{2}$ vary much more slowly than $\mathrm{OH}$ at low $\mathrm{NO}_{\mathrm{x}}$ mixing ratios, even when $\mathrm{HO}_{\mathrm{x}}$ self reactions become the dominant chain termination step (e.g. Thornton et al., 2002).

$A$ variety of methods have been used to combine calculations and observations to 4821

ACPD

$5,4801-4843,2005$

Total alkyl nitrates within the

Sacramento Urban Plume

P. A. Cleary et al.

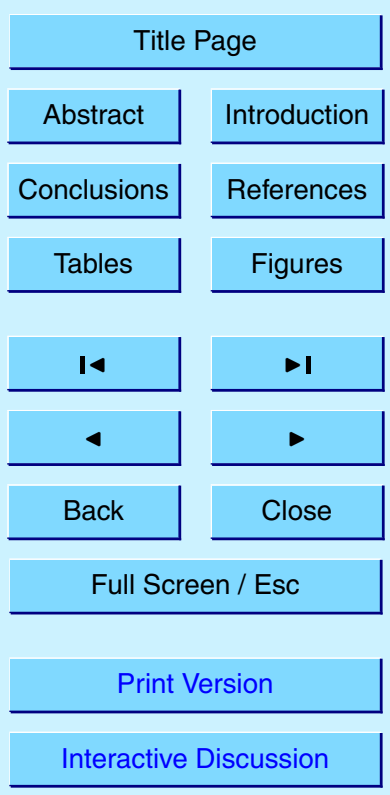

EGU 
infer free radical chain lengths for the $\mathrm{HO}_{\mathrm{x}}$ and $\mathrm{NO}_{\mathrm{x}}$ cycles. One common method (Sillman, 1995, 1999) and references therein) is to examine the slope of $\mathrm{O}_{\mathrm{x}} \mathrm{vs} . \mathrm{NO}_{z}$, where $\mathrm{NO}_{z}$ is usually defined as $\mathrm{NO}_{y}-\mathrm{NO}_{\mathrm{x}}$ and is approximately equal to the sum of $\mathrm{HNO}_{3}, \Sigma$ ANs and $\Sigma \mathrm{PNs}$. The slope is used to indicate the relative rates of $\mathrm{O}_{3}$ produc5 tion versus chain termination, in the form of $\mathrm{NO}_{\mathrm{x}}$ oxidation to $\mathrm{NO}_{z}$. Typical slopes of $\mathrm{O}_{\mathrm{x}}$ vs. $\mathrm{NO}_{z}$ for urban plumes are in the range 5-15. During summer, when $\Sigma P N$ lifetimes are short, this definition overestimates the rate of chain termination. Here we use $\mathrm{O}_{x}$ vs. $\mathrm{HNO}_{3}+\Sigma \mathrm{ANs}$ as our indicator of the relative rates of ozone production and chain termination. The slope of $\mathrm{O}_{\mathrm{x}} \mathrm{vs}$. $\mathrm{HNO}_{3}+\Sigma \mathrm{ANs}$ at Granite Bay is 12.5 in the morning 10 (09:00-12:00 h) when we expect deposition to have the smallest effects on our interpretation of the correlation, and 16 for the full dataset. Neglecting deposition or dilution, these slopes are equal to the $\mathrm{NO}_{\mathrm{x}}$ chain length and are twice the $\mathrm{HO}_{\mathrm{x}}$ chain length. Typically $\Sigma A N s$ are between $1 / 4$ and $1 / 5$ of the sum of $\Sigma A N s$ and $\mathrm{HNO}_{3}$ suggesting that $\Sigma$ ANs represent $20-25 \%$ of the chain termination events.

A second approach to determining the $\mathrm{NO}_{x}$ and $\mathrm{HO}_{x}$ chain lengths is to calculate them directly from the observed hydrocarbons and speciated $\mathrm{NO}_{\mathrm{y}}$ measurements. Using the VOC data from Table 1 and the median $\mathrm{NO}_{2}$ observed during the corresponding 09:00-12:00 h time period of $5.62 \mathrm{ppb}$, we find the loss rate of $\mathrm{OH}$ to $\mathrm{VOC}$ is $8.21 \mathrm{~s}^{-1}$, the loss rate to $\mathrm{NO}_{2}$ is $1.42 \mathrm{~s}^{-1}$. Adding in the additional termination step to $\Sigma A N$ forma20 tion corresponding to $4.2 \%$ of the loss to VOC (i.e. a termination rate to $\Sigma A N$ formation of $0.345 \mathrm{~s}^{-1}$ ) results in a calculated $\mathrm{HO}_{\mathrm{x}}$ chain length of 4.65 and thus a $\mathrm{NO}_{\mathrm{x}}$ chain length of 9.30. $\Sigma$ AN formation is calculated to be $20 \%$ of the chain termination events. These numbers are shorter than derived from the correlation of $\mathrm{O}_{x} \mathrm{vs} . \mathrm{HNO}_{3}+\Sigma A N s$, as we expect based on the assumption that $\mathrm{HNO}_{3}$ and hydroxyalkyl-nitrates deposit 25 faster than does $\mathrm{O}_{\mathrm{x}}$.

ACPD

$5,4801-4843,2005$

\section{Total alkyl nitrates within the \\ Sacramento Urban Plume}

P. A. Cleary et al.

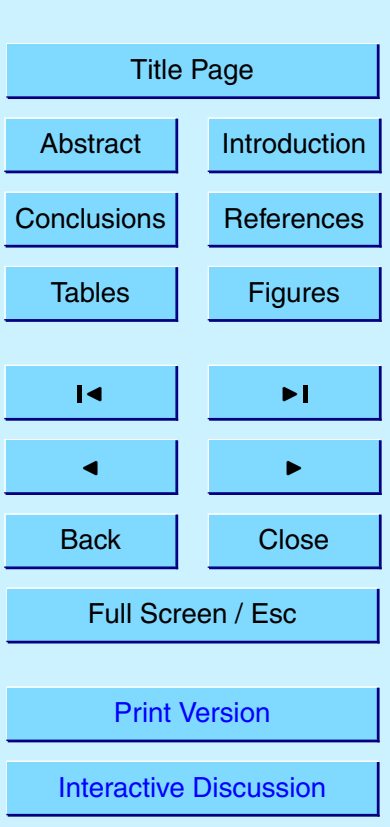




\section{Conclusions}

We have described observations of sources and products of the major catalytic cycles governing urban and regional photochemistry: VOC, $\mathrm{NO}_{2}, \Sigma \mathrm{ANs}, \mathrm{HNO}_{3}$ and $\mathrm{O}_{3}$. Our observations show that $\Sigma$ ANs are a photoproduct of oxidation of urban hydrocarbon 5 mixtures with approximately one alkyl nitrate produced for every 25 molecules of $\mathrm{O}_{3}$. The modeled alkyl nitrate yield of $3.7 \%$ is within the uncertainty of the observed yield (best estimate $4.2 \%$ and an estimated range of $4-6 \%$ ) analysis of $\mathrm{O}_{x}$ and $\Sigma A N s$. These measurements emphasize the importance of $\Sigma A N$ formation as a chain termination step and suggest that a more complete and quantitative description of $\Sigma A N$ formation 10 than is present in current reduced mechanisms (Luecken et al., 1999) will be required for accurate models of urban and regional $\mathrm{O}_{3}$.

\section{Appendix A}

In order to account for well-known sources of ozone, we estimate abundances of several VOC. We do not have measurements of the lightest hydrocarbons: $\mathrm{CO}$, 15

$\mathrm{CH}_{4}$, ethane, ethene, acetylene or formaldehyde. We use the ratio of $\mathrm{CO} / \mathrm{NO}_{\mathrm{y}}$ of $20 \mathrm{ppbv} / \mathrm{ppbv}$ observed in Sacramento in the morning (CARB, 1999) to estimate CO to be $190 \mathrm{ppbv}$ using the $\Sigma \mathrm{NO}_{\text {yi }}$ measurements. We estimate $\mathrm{CH}_{4}$ as $1.7 \mathrm{ppmv}$ assuming it is equal to the global average mixing ratio (Dlugokencky et al., 1998). We use the average hydrocarbon ratios observed in experiments at comparable locations (Lamanna and Goldstein, 1999; Parrish et al., 1998) to estimate mixing ratios of 0.4 and $0.1 \mathrm{ppbv}$ for ethene and acetylene. We estimate $4 \mathrm{ppbv}$ formaldehyde based on observations from Sauer et al. (2003) in Parker, CA. The mixing ratio for ethane is estimated from the ratio of 2:1 ethane to propane observed by Goldstein et al. (1995). Concentrations of propanal, octanal, heptanal and nonanal are estimated using ratios of the reactivity of these compounds to the reactivity of the largest aldehyde we did measure, hexanal. We scale to ratios of reactivities reported in Bowman et al. (2003).
ACPD

$5,4801-4843,2005$

Total alkyl nitrates within the

\section{Sacramento Urban} Plume

P. A. Cleary et al.

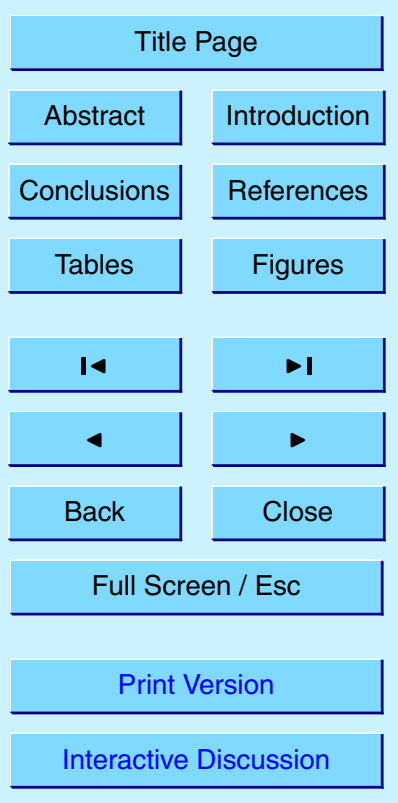


We also do not have observations of many heavy alkanes, aldehydes or $\beta$-pinene. We estimate the mixing ratios of octane and nonane using their ratios to i-pentane and set the ratio to the median of the range described by Parrish, et al. (1998). Observations of the ratio of $\beta$-pinene to $\alpha$-pinene, which we did measure, range from 1-3 (Ciccioli 5 et al., 1999; McKeen et al., 1997; Schade et al., 1999). The value of 3 from McKeen is more likely comparable to our site because of many similarities in VOC ratios, giving an estimate of $\beta$-pinene of $0.04 \mathrm{ppbv}$ and its contribution to the production of $\mathrm{O}_{3}$ of $0.72 \%$. There is limited data available for other members of the terpene family. Based on results from Schade et al. (1999) and other observations made at Blodgett Forest 10 (A. Lee, personal communication), the sum of all terpenes is likely twice the sum of $\alpha$ - and $\beta$-pinene and we estimate them as such. We also estimate the contribution to ozone production from the photolysis of formaldehyde and acetone (Table 2). Other secondary oxidation products, including and analogous to the C5-hydroxyaldehydes produced during isoprene oxidation, are important contributors to $\mathrm{P}_{\mathrm{O} 3}$. We derive the 15 mixing ratio of the C5-hydroxyaldehydes using the ratio to MVK from Sprengnether et al. (2002). Little is known about their reactivity. We estimate that it is similar to that of glycoaldehyde (Bacher et al., 2001). The sum of total terpenoid oxidation products is estimated by analogy to be in the same ratio as the sum of isoprene oxidation products to isoprene. We also include estimates of oxygenated species like MBO, glyoxal and hydroxyacetone as similar to those from measurements at Blodgett Forest (Spaulding et al., 2003). Since methyl glyoxal is a product of MVK oxidation, and we have an estimation of $20 \%$ loss of MVK to $\mathrm{OH}$, and the branching ratio of 0.3 to methyl glyoxal formation in the oxidation of MVK, we calculate from an average morning concentration of MVK of $0.53 \mathrm{ppbv}$, a methyl glyoxal concentration of $0.030 \mathrm{ppbv}$. This abundance is roughly $\frac{1}{4}$ the amount measured at Blodgett Forest. We then scale all other oxygenated species measured by Spaulding et al. (2003) at Blodgett Forest by this same $25 \%$ to represent the fewer biogenic emissions around Granite Bay.

Acknowledgements. We gratefully acknowledge the US Department of Energy support for measurements under contract AC03-76SF0009 and the EPA for support for analysis under

ACPD

$5,4801-4843,2005$

Total alkyl nitrates within the

Sacramento Urban Plume

P. A. Cleary et al.

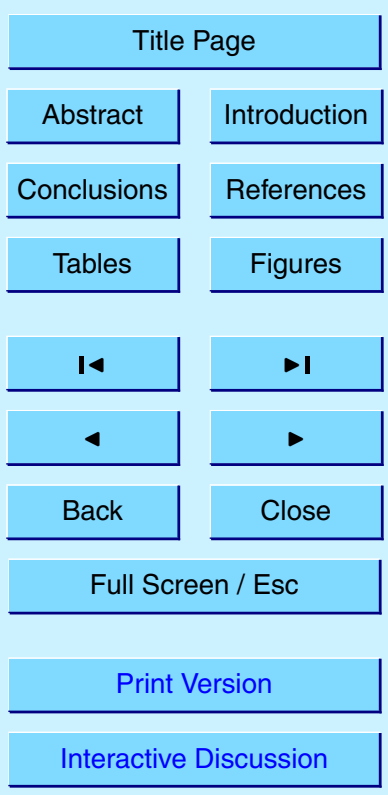

EGU 
grant RD-83096401-0. Although the research described in this article has been funded in part by the United States Environmental Protection Agency through a grant agreement to the University of California, Berkeley, it has not been subjected to the Agency's required peer and policy review and therefore does not necessarily reflect the views of the Agency and no offi5 cial endorsement should be inferred. D. Millet also acknowledges a DOE GCEP fellowship for funding. We are grateful to the Eureka Union School District for the use of the site.

\section{References}

Arey, J., Aschmann, S. M., Kwok, E. S. C., and Atkinson, R.: Alkyl nitrate, hydroxyalkyl nitrate, and hydroxycarbonyl formation from the $\mathrm{NO}_{x}$-air photooxidations of $\mathrm{C}_{5}-\mathrm{C}_{8}$ n-alkanes, J. Phys. Chem., 105, 1020-1027, 2001.

Atkinson, R.: Gas-Phase Tropospheric Chemistry of Organic-Compounds, J. Phys. Chem. Ref. Data Monograph, 2, 1, 1994.

Atkinson, R.: Gas-phase tropospheric chemistry of volatile organic compounds 1. Alkanes and alkenes, J. Phys. Chem. Ref. Data, 26, 215-290, 1997.

15 Atkinson, R., Aschmann, S. M., Carter, W. P. L., Winer, A. M., and Pitts, J. N.: Alkyl Nitrate Formation From the $\mathrm{NO}_{x}$-Air Photooxidations of $\mathrm{C}_{2}-\mathrm{C}_{8}$ n-Alkanes, J. Phys. Chem., 86, 45634569, 1982.

Atkinson, R., Aschmann, S. M., Tuazon, E. C., Arey, J., and Zielinska, B.: Formation of 3Methylfuran From the Gas-Phase Reaction of $\mathrm{OH}$ Radicals With Isoprene and the RateConstant For Its Reaction With the OH Radical, Int. J. Chem. Kinetics, 21, 593-604, 1989.

Bacher, C., Tyndall, G. S., and Orlando, J. J.: The atmospheric chemistry of glycolaldehyde, J. Atmos. Chem., 39, 171-189, 2001.

Bari, A., Ferraro, V., Wilson, L. R., Luttinger, D., and Husain, L.: Measurements of gaseous $\mathrm{HONO}, \mathrm{HNO}_{3}, \mathrm{SO}_{2}, \mathrm{HCl}, \mathrm{NH}_{3}$, particulate sulfate and PM2.5 in New York, NY, Atmos. Environ., 37, 2825-2835, 2003.

Bertman, S. B., Roberts, J. M., Parrish, D. D., Buhr, M. P., Goldan, P. D., Kuster, W. C., Fehsenfeld, F. C., Montzka, S. A., and Westberg, H.: Evolution of Alkyl Nitrates With Air-Mass Age, J. Geophys. Res., 100, 22 805-22 813, 1995.

Bertram, T. H. and Cohen, R. C.: A prototype instrument for the detection of semi-volatile organic and inorganic nitrate aerosol, Eos Trans. AGU, 84, 2003.
ACPD

5, 4801-4843, 2005

Total alkyl nitrates within the

Sacramento Urban Plume

P. A. Cleary et al.

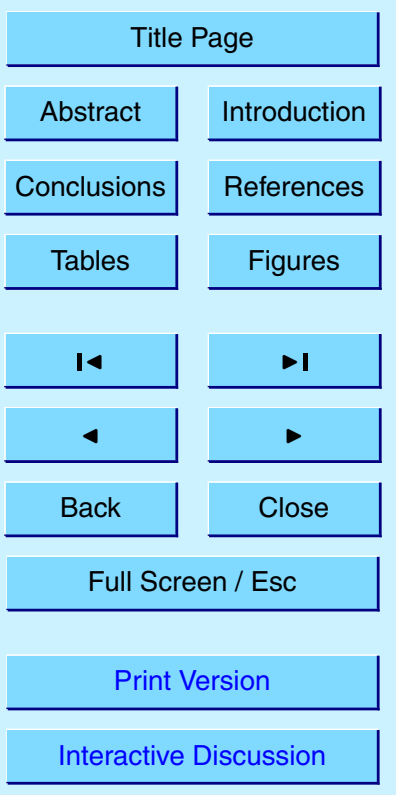


CARB: Ambient air quality data: 1980-1998, pp. Rep PTSD-99-012-CD, California Air Resources Board, Sacramento, CA, 1999.

Carroll, J. J. and Dixon, A. J.: Tracking the sacramento pollutant plume over the western Sierra Nevada, California Air Resources Board, Sacramento, CA, 1998.

5 Chen, X. H., Hulbert, D., and Shepson, P. B.: Measurement of the organic nitrate yield from $\mathrm{OH}$ reaction with isoprene, J. Geophys. Res., 103, 25563-25568, 1998.

Chuong, B. and Stevens, P. S.: Measurements of the kinetics of the $\mathrm{OH}$-initiated oxidation of isoprene, J. Geophys. Res., 107, art. no. 4162, 2002.

Ciccioli, P., Brancaleoni, E., Frattoni, M., Di Palo, V., Valentini, R., Tirone, G., Seufert, G., Bertin, N., Hansen, U., Csiky, O., Lenz, R., and Sharma, M.: Emission of reactive terpene compounds from orange orchards and their removal by within-canopy processes, J. Geophys. Res., 104, 8077-8094, 1999.

Cleary, P. A.: Nitrogen oxides and ozone production in the Sacramento Urban Plume, PhD thesis, University of California, Berkeley, 2003.

Cleary, P. A., Wooldridge, P. J., and Cohen, R. C.: Laser-induced fluorescence detection of atmospheric $\mathrm{NO}_{2}$ with a commercial diode laser and a supersonic expansion, Appl. Opt., 41, 6950-6956, 2002.

Day, D. A., Dillon, M. B., Wooldridge, P. J., Thornton, J. A., Rosen, R. S., Wood, E. C., and Cohen, R. C.: On alkyl nitrates, $\mathrm{O}_{3}$, and the "missing NO,", J. Geophys. Res., 108, doi:10.1029/2003JD003685, 2003.

Day, D. A., Murphy, J. G., Dillon, M. B., Wooldridge, P. J., and Cohen, R. C.: Observations of the Summertime Diurnal Cycles of $\mathrm{NO}_{\mathrm{x}}, \Sigma \mathrm{PNs}, \Sigma \mathrm{ANs}$, and $\mathrm{HNO}_{3}$ at a Rural Site in the California Sierra Nevada Mountains, J. Geophys. Res., in preparation, 2005.

Day, D. A., Wooldridge, P. J., Dillon, M. B., Thornton, J. A., and Cohen, R. C.: A thermal dissociation laser-induced fluorescence instrument for in situ detection of $\mathrm{NO}_{2}$, peroxy nitrates, alkyl nitrates, and $\mathrm{HNO}_{3}$, J. Geophys. Res., 107, art. no. 4046, 2002.

Di Carlo, P., Brune, W. H., Martinez, M., Harder, H., Lesher, R., Ren, X. R., Thornberry, T., Carroll, M. A., Young, V., Shepson, P. B., Riemer, D., Apel, E., and Campbell, C.: Missing OH reactivity in a forest: Evidence for unknown reactive biogenic VOCs, Science, 304, 722-725, 302004.

Dillon, M. B., Lamanna, M. S., Schade, G. W., Goldstein, A. H., and Cohen, R. C.: Chemical evolution of the Sacramento urban plume: Transport and oxidation, J. Geophys. Res., 107, art. no. 4045, 2002a.

ACPD

5, 4801-4843, 2005

\section{Total alkyl nitrates within the \\ Sacramento Urban Plume}

P. A. Cleary et al.

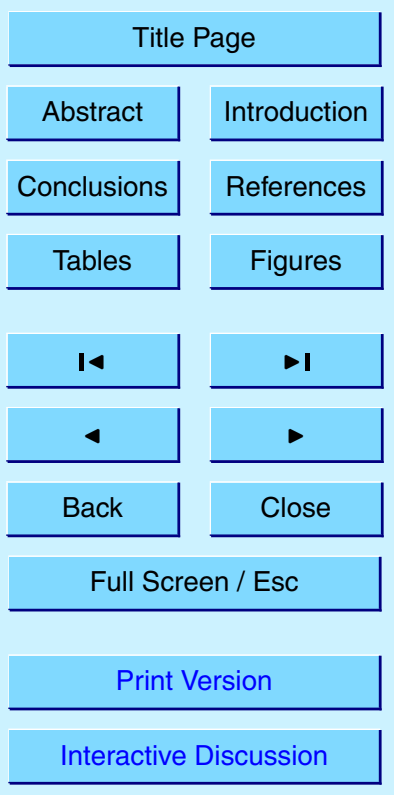

EGU 
Dillon, M. B., Lamanna, M. S., Schade, G. W., Goldstein, A. H., and Cohen, R. C.: Chemical evolution of the Sacramento urban plume: Transport and oxidation, J. Geophys. Res., 107, art. no. 4045, 2002b.

Dlugokencky, E. J., Masarie, K. A., Lang, P. M., and Tans, P. P.: Continuing decline in the growth rate of the atmospheric methane burden, Nature, 393, 447-450, 1998.

Dreyfus, G. B., Schade, G. W., and Goldstein, A. H.: Observational constraints on the contribution of isoprene oxidation to ozone production on the western slope of the Sierra Nevada, California, J. Geophys. Res., 107, 4365, doi:10.1029/2001JD001490, 2002.

Fischer, R., Weller, R., Jacobi, H. W., and Ballschmiter, K.: Levels and pattern of volatile organic nitrates and halocarbons in the air at Neumayer Station (70 degrees S), Antarctic, Chemosphere, 48, 981-992, 2002.

Fischer, R. G., Kastler, J., and Ballschmiter, K.: Levels and pattern of alkyl nitrates, multifunctional alkyl nitrates, and halocarbons in the air over the Atlantic Ocean, J. Geophys. Res., 105, 14 473-14 494, 2000.

Flocke, F., Volz-Thomas, A., Buers, H. J., Patz, W., Garthe, H. J., and Kley, D.: Long-term measurements of alkyl nitrates in southern Germany 1 . General behavior and seasonal and diurnal variation, J. Geophys. Res., 103, 5729-5746, 1998.

Goldstein, A. H., McKay, M., Kurpius, M. R., Schade, G. W., Lee, A., Holzinger, R., and Rasmussen, R. A.: Forest thinning experiment confirms ozone deposition to forest canopy is dominated by reaction with biogenic VOCs, Geophys. Res. Lett., 31, doi:10.1029/2004GL021259, 2004.

Goldstein, A. H., Wofsy, S. C., and Spivakovsky, C. M.: Seasonal Variations of Nonmethane Hydrocarbons in Rural New England - Constraints On OH Concentrations in Northern Midlatitudes, J. Geophys. Res., 100, 21 023-21 033, 1995.

Grosjean, D.: Ambient PAN and PPN in southern California from 1960 to the Scos97NARSTO, Atmos. Environ., 37, S221-S238, 2003.

Grossenbacher, J. W., Barket, D. J., Shepson, P. B., Carroll, M. A., Olszyna, K., and Apel, E.: A comparison of isoprene nitrate concentrations at two forest-impacted sites, J. Geophys. Res., 109, doi:10.1029/2003JD003966, 2004.

30 Grossenbacher, J. W., Couch, T., Shepson, P. B., Thornberry, T., Witmer-Rich, M., Carroll, M. A., Faloona, I., Tan, D., Brune, W., Ostling, K., and Bertman, S.: Measurements of isoprene nitrates above a forest canopy, J. Geophys. Res., 106, 24 429-24 438, 2001.

Hsu, K. J. and Demore, W. B.: Rate Constants For the Reactions of Oh With $\mathrm{CH}_{3} \mathrm{Cl}_{,} \mathrm{CH}_{2} \mathrm{Cl}_{2}$,

ACPD

5, 4801-4843, 2005

\section{Total alkyl nitrates within the \\ Sacramento Urban Plume}

P. A. Cleary et al.

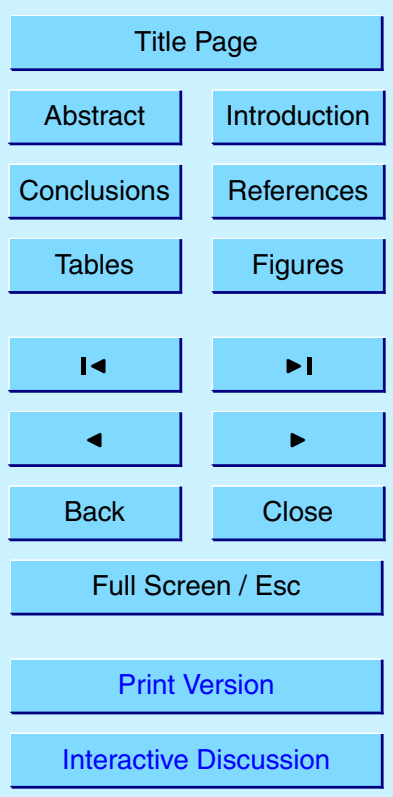

EGU 
Chcl3, and Ch3br, Geophys. Res. Lett., 21, 805-808, 1994.

Hurst Bowman, J., Basket, D. J., and Shepson, P. B.: Atmospheric chemistry of nonanal, Environ. Sci. Technol., 38, 2218-2225, 2003.

Kastler, J., Jarman, W., and Ballschmiter, K.: Multifunctional organic nitrates as constituents in

$5 \quad$ European and US urban photo-smog, Fresenius J. Anal. Chem., 368, 244-249, 2000.

Kolb, C. E., Herndon, S. C., McManus, B., Shorter, J. H., Zahniser, M. S., Nelson, D. D., Jayne, J. T., Canagaratna, M. R., and Worsnop, D. R.: Mobile laboratory with rapid response instruments for real-time measurements of urban and regional trace gas and particulate distributions and emission source characteristics, Environ. Sci. Technol., 38, 5694-5703, 2004.

Kwok, E. S. C. and Atkinson, R.: Estimation of Hydroxyl Radical Reaction-Rate Constants For Gas-Phase Organic-Compounds Using a Structure-Reactivity Relationship - an Update, Atmos. Environ., 29, 1685-1695, 1995.

Lamanna, M. S. and Goldstein, A. H.: In situ measurements of C-2-C-10 volatile organic com15 pounds above a Sierra Nevada ponderosa pine plantation, J. Geophys. Res., 104, $21247-$ $21262,1999$.

Liang, J. Y., Horowitz, L. W., Jacob, D. J., Wang, Y. H., Fiore, A. M., Logan, J. A., Gardner, G. M., and Munger, J. W.: Seasonal budgets of reactive nitrogen species and ozone over the United States, and export fluxes to the global atmosphere, J. Geophys. Res., 103, 13435-13450, 1998.

Lightfoot, P. D., Cox, R. A., Crowley, J. N., Destriau, M., Hayman, G. D., Jenkin, M. E., Moortgat, G. K., and Zabel, F.: Organic Peroxy-Radicals - Kinetics, Spectroscopy and Tropospheric Chemistry, Atmos. Environ. Part a-General Topics, 26, 1805-1961, 1992.

Luecken, D. J., Tonnesen, G. S., and Sickles, J. E.: Differences in $\mathrm{NO}_{y}$ speciation predicted by three photochemical mechanisms, Atmos. Environ., 33, 1073-1084, 1999.

Luxenhofer, O., Schneider, M., Dambach, M., and Ballschmiter, K.: Semivolatile long chain $\mathrm{C}_{6}-\mathrm{C}_{17}$ alkyl nitrates as trace compounds in air, Chemosphere, 33, 393-404, 1996.

McKeen, S. A., Mount, G., Eisele, F., Williams, E., Harder, J., Goldan, P., Kuster, W., Liu, S. C., Baumann, K., Tanner, D., Fried, A., Sewell, S., Cantrell, C., and Shetter, R.: Photochemical modeling of hydroxyl and its relationship to other species during the Tropospheric $\mathrm{OH}$ Photochemistry Experiment, J. Geophys. Res., 102, 6467-6493, 1997.

Millet, D. B., Dohahue, N. M., Pandis, S. N., Polidori, C. O., Stanier, D. O., Turpin, B. J., and Goldstein, A. H.: Atmospheric VOC measurements during the Pittsburgh Air Quality Study:
ACPD

5, 4801-4843, 2005

Total alkyl nitrates within the

Sacramento Urban Plume

P. A. Cleary et al.

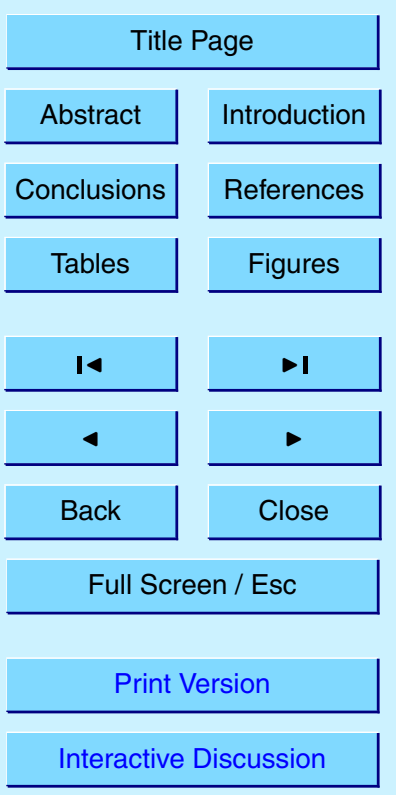

EGU 
Results, interpretation and quantification of primary and secondary contributions, J. Geophys. Res., 110, doi:10.1029/2004JD004601, 2004.

Navas, M. J., Jimenez, A. M., and Galan, G.: Air analysis: Determination of nitrogen compounds by chemiluminescence, Atmos. Environ., 31, D07S07, 3603, 1997.

5 Neuman, J. A., Huey, L. G., Dissly, R. W., Fehsenfeld, F. C., Flocke, F., Holecek, J. C., Holloway, J. S., Hubler, G., Jakoubek, R., Nicks, D. K., Parrish, D. D., Ryerson, T. B., Sueper, D. T., and Weinheimer, A. J.: Fast-response airborne in situ measurements of $\mathrm{HNO}_{3}$ during the Texas 2000 Air Quality Study, J. Geophys., Res., 107, art. no. 4436, 2002.

NOAA-ARL: HYSPLIT4 (HYbrid Single-Particle Lagrangian Integrated Trajectory) Model, 1997. http://www.arl.noaa.gov/ready/hysplit4.html

Noziere, B., Barnes, I., and Becker, K. H.: Product study and mechanisms of the reactions of alpha-pinene and of pinonaldehyde with $\mathrm{OH}$ radicals, J. Geophys. Res., 104, 23645-23656, 1999.

O'Brien, J. M., Czuba, E., Hastie, D. R., Francisco, J. S., and Shepson, P. B.: Determination of the hydroxy nitrate yields from the reaction of $\mathrm{C}_{2}-\mathrm{C}_{6}$ alkenes with $\mathrm{OH}$ in the presence of $\mathrm{NO}$, J. Phys. Chem., 102, 8903-8908, 1998.

O'Brien, J. M., Shepson, P. B., Muthuramu, K., Hao, C., Niki, H., Hastie, D. R., Taylor, R., and Roussel, P. B.: Measurements of Alkyl and Multifunctional Organic Nitrates At a Rural Site in Ontario, J. Geophys. Res., 100, 22 795-22 804, 1995.

O'Brien, J. M., Shepson, P. B., Wu, Q., Biesenthal, T., Bottenheim, J. W., Wiebe, H. A., Anlauf, K. G., and Brickell, P.: Production and distribution of organic nitrates, and their relationship to carbonyl compounds in an urban environment, Atmos. Environ., 31, 2059-2069, 1997.

Ostling, K., Kelly, B., Bird, S., Bertman, S., Pippin, M., Thornberry, T., and Carroll, M. A.: Fast-turnaround alkyl nitrate measurements during the PROPHET 1998 summer intensive, J. Geophys. Res., 106, 24 439-24 449, 2001.

Papagni, C., Arey, J., and Atkinson, R.: Rate constants for the gas-phase reactions of a series of $\mathrm{C}_{3}-\mathrm{C}_{6}$ aldehydes with $\mathrm{OH}$ and $\mathrm{NO}_{3}$ radicals, Int. J. Chem. Kinetics, 32, 79-84, 2000.

Parrish, D. D., Trainer, M., Young, V., Goldan, P. D., Kuster, W. C., Jobson, B. T., Fehsenfeld, F. C., Lonneman, W. A., Zika, R. D., Farmer, C. T., Riemer, D. D., and Rodgers, M. O.: Internalconsistency tests for evaluation of measurements of anthropogenic hydrocarbons in the troposphere, J. Geophys. Res., 103, 22 339-22 359, 1998.

Poschl, U., von Kuhlmann, R., Poisson, N., and Crutzen, P. J.: Development and intercomparison of condensed isoprene oxidation mechanisms for global atmospheric modeling, J. Atmo.

ACPD

5, 4801-4843, 2005

\section{Total alkyl nitrates within the \\ Sacramento Urban Plume}

P. A. Cleary et al.

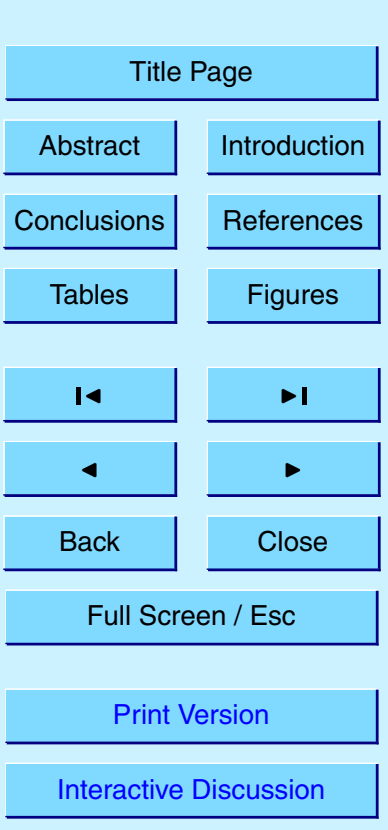

EGU 
Chem., 37, 29-52, 2000.

Ranschaert, D. L., Schneider, N. J., and Elrod, M. J.: Kinetics of the $\mathrm{C}_{2} \mathrm{H}_{5} \mathrm{O}_{2}+\mathrm{NO}_{\mathrm{x}}$ reactions: Temperature dependence of the overall rate constant and the $\mathrm{C} 2 \mathrm{H} 5 \mathrm{ONO} 2$ branching channel of $\mathrm{C}_{2} \mathrm{H}_{5} \mathrm{O}_{2}+\mathrm{NO}$, J. Phys. Chem., 104, 5758-5765, 2000.

5 Roberts, J. M., Bertman, S. B., Parrish, D. D., Fehsenfeld, F. C., Jobson, B. T., and Niki, H.: Measurement of alkyl nitrates at Chebogue Point, Nova Scotia during the 1993 North Atlantic Regional Experiment (NARE) intensive, J. Geophys. Res., 103, 13569-13580, 1998.

Roberts, J. M., Flocke, F., Stroud, C. A., Hereid, D., Williams, E., Fehsenfeld, F., Brune, W., Martinez, M., and Harder, H.: Ground-based measurements of peroxycarboxylic nitric anhydrides (PANs) during the 1999 Southern Oxidants Study Nashville Intensive, Journal of Geophysical Research-Atmospheres, 107, art. no. 4554, 2002.

Roberts, J. M., Stroud, C. A., Jobson, B. T., Trainer, M., Hereid, D., Williams, E., Fehsenfeld, F., Brune, W., Martinez, M., and Harder, H.: Application of a sequential reaction model to PANs and aldehyde measurements in two urban areas, Geophys. Res. Lett., 28, 4583-4586, 2001.

Rosen, R. S., Wood, E. C., Wooldridge, P. J., Thornton, J. A., Day, D. A., Kuster, W., Williams, E. J., Jobson, B. T., and Cohen, R. C.: Observations of total alkyl nitrates during Texas Air Quality Study 2000: Implications for $\mathrm{O}_{3}$ and alkyl nitrate photochemistry, J. Geophys. Res., 109, D07303, 7303, 2004.

Sauer, C. G., Pisano, J. T., and Fitz, D. R.: Tunable diode laser absorption spectrometer measurements of ambient nitrogen dioxide, nitric acid, formaldehyde, and hydrogen peroxide in Parlier, California, Atmos. Environ., 37, 1583-1591, 2003.

Schade, G. W. and Goldstein, A. H.: Fluxes of oxygenated volatile organic compounds from a ponderosa pine plantation, J. Geophys. Res., 106, 3111-3123, 2001.

Schade, G. W., Goldstein, A. H., and Lamanna, M. S.: Are monoterpene emissions influenced by humidity?, Geophys. Res. Lett., 26, 2187-2190, 1999.

Seinfeld, J. H. and Pandis, S. N.: Atmospheric chemistry and physics: From air pollution to climate change, John Wiley \& Sons, Inc., New York, 1998.

Shepson, P. B., Hastie, D. R., and Niki, H.: Impact of Toronto Urban Emissions On Ozone Levels Downwind, Atmos. Environ., 30, 2177-2193, 1996.

Sillman, S.: The use of $\mathrm{NO}_{\mathrm{y}}, \mathrm{H}_{2} \mathrm{O}_{2}$, and $\mathrm{HNO}_{3}$ as indicators for ozone- $\mathrm{NO}_{\mathrm{x}}$-hydrocarbon sensitivity in urban locations, J. Geophys. Res., 100, 14 175-14 188, 1995.

Sillman, S., Dongyang, H., Pippin, M. R., Daum, P. H., Imre, D. G., Kleinman, L. I., Jai Hoon, L.,

\section{ACPD}

5, 4801-4843, 2005

Total alkyl nitrates within the

\section{Sacramento Urban} Plume

P. A. Cleary et al.

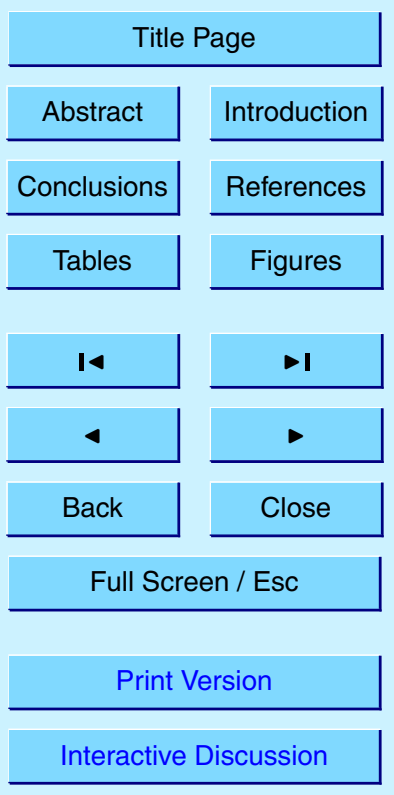

EGU 
and Weinstein-Lloyd, J.: Model correlations for ozone, reactive nitrogen, and peroxides for Nashville in comparison with measurements: implications for $\mathrm{O}_{3}-\mathrm{NO}_{\mathrm{x}}$-hydrocarbon chemistry, J. Geophys. Res., 103, 22 629-22 644, 1998.

Sillman, S.: The relation between ozone, NOx and hydrocarbons in urban and polluted rural environments, Atmos. Environ., 33, 1821-1845, 1999.

Spaulding, R. S., Schade, G. W., Goldstein, A. H., and Charles, M. J.: Characterization of secondary atmospheric photooxidation products: Evidence for biogenic and anthropogenic sources, J. Geophys. Res., 108, doi:10.1029/2002JD002478, 2003.

Sprengnether, M., Demerjian, K. L., Donahue, N. M., and Anderson, J. G.: Product analysis of the $\mathrm{OH}$ oxidation of isoprene and 1,3-butadiene in the presence of NO, J. Geophys. Res., 107, U146-U158, art. no. 4269, 2002.

Thornton, J. A., Wooldridge, P. J., and Cohen, R. C.: Atmospheric $\mathrm{NO}_{2}$ : In situ laser-induced fluorescence detection at parts per trillion mixing ratios, Analytical Chemistry, 72, 528-539, 2000.

Thornton, J. A., Wooldridge, P. J., Cohen, R. C., Martinez, M., Harder, H., Brune, W. H., Williams, E. J., Roberts, J. M., Fehsenfeld, F. C., Hall, S. R., Shetter, R. E., Wert, B. P., and Fried, A.: Ozone production rates as a function of $\mathrm{NO}_{\mathrm{x}}$ abundances and $\mathrm{HO}_{\mathrm{x}}$ production rates in the Nashville urban plume, J. Geophys. Res., 107, art. no. 4146, 2002.

Trainer, M., Buhr, M. P., Curran, C. M., Fehsenfeld, F. C., Hsie, E. Y., Liu, S. C., Norton, R. B., Parrish, D. D., Williams, E. J., Gandrud, B. W., Ridley, B. A., Shetter, J. D., Allwine, E. J., and Westberg, H. H.: Observations and Modeling of the Reactive Nitrogen Photochemistry At a Rural Site, J. Geophys. Res., 96, 3045-3063, 1991.

Tuazon, E. C. and Atkinson, R.: A Product Study of the Gas-Phase Reaction of Isoprene With the $\mathrm{OH}$ Radical in the Presence of $\mathrm{NO}_{\mathrm{x}}$, Int. J. Chem. Kinetics, 22, 1221-1236, 1990.

UCAR: TUV (Total Ultraviolet and Visible radiation model), 2002. http://www.acd.ucar.edu/TUV/

Werner, G., Kastler, J., Looser, R., and Ballschmiter, K.: Organic nitrates of isoprene as atmospheric trace compounds, Angewandte Chemie-International Edition, 38, 1634-1637, 1999.
ACPD

$5,4801-4843,2005$

\section{Total alkyl nitrates within the \\ Sacramento Urban Plume}

P. A. Cleary et al.

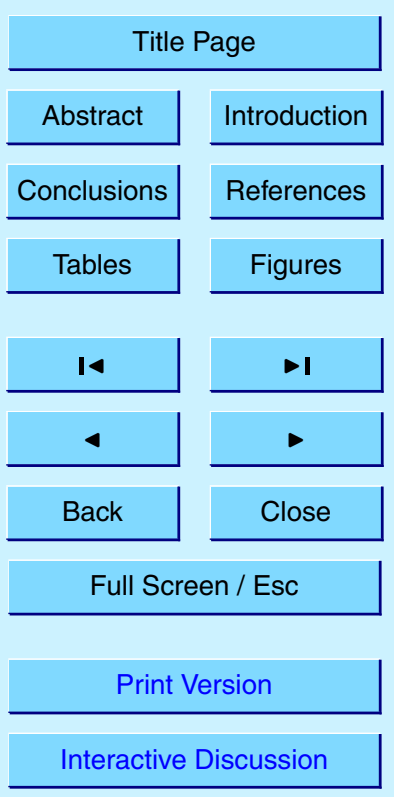


Table 1. Mean of the measured VOC mixing ratios (09:00-12:00 LT) and estimates of other VOC along with rate constants with $\mathrm{OH}$, the number of ozone produced per VOC oxidized, $\gamma$, and branching ratios for alkyl nitrate formation, $\alpha$, are also listed.

\begin{tabular}{|c|c|c|c|c|c|c|}
\hline compound & $\begin{array}{l}\text { mixing ratio } \\
\text { (ppbv) }\end{array}$ & $\begin{array}{l}\mathrm{k}_{\mathrm{OH}}^{\mathrm{a}} \times 10^{11} \\
\text { molec. } \mathrm{cm}^{-3} \mathrm{~s}^{-1}\end{array}$ & $\gamma^{\mathrm{a}}$ & $\alpha$ & 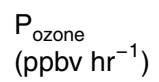 & $\begin{array}{l}\mathrm{P}_{\Sigma A N s} \\
\left(\mathrm{ppbv} \mathrm{hr}^{-1}\right)\end{array}$ \\
\hline \multicolumn{7}{|l|}{ Alkanes } \\
\hline $\mathrm{CH}_{4}$ & $1700^{*}$ & 0.0006 & 2 & 0.005 & 0.384 & 0.00096 \\
\hline $\mathrm{CH}_{2} \mathrm{Cl}_{2}$ & 0.077 & $0.0082^{\prime}$ & 2 & $0^{*}$ & 0.0002 & 0.00000 \\
\hline $\mathrm{CHCl}_{3}$ & 0.017 & $0.0088^{l}$ & 2 & $0^{*}$ & 0.0001 & 0.00000 \\
\hline $\mathrm{CH}_{3} \mathrm{Cl}$ & 0.600 & 0.0053 & 2 & $0^{*}$ & 0.001 & 0.00000 \\
\hline ethane & $2^{* e}$ & 0.0257 & 2 & $0.006^{v}$ & 0.018 & 0.00009 \\
\hline propane & 1.005 & 0.115 & 2 & $0.036^{\mathrm{w}}$ & 0.040 & 0.00075 \\
\hline n-butane & 0.315 & 0.254 & $2.85^{* r}$ & $0.073^{x}$ & 0.038 & 0.00105 \\
\hline iso-butane & 0.228 & 0.233 & $2.85^{* r}$ & $0.255^{\mathrm{y}}$ & 0.020 & 0.00244 \\
\hline pentane & 0.199 & 0.394 & $2.85^{* r}$ & $0.105^{x}$ & 0.036 & 0.00148 \\
\hline iso-pentane & 0.541 & 0.39 & $2.85^{* r}$ & $0.07^{y}$ & 0.095 & 0.00456 \\
\hline cyclopentane & 0.030 & 0.508 & $2.85^{* r}$ & $0.10^{*}$ & 0.007 & 0.00028 \\
\hline 2,2-dimethylpentane & 0.005 & 0.340 & $2.85^{* r}$ & $0.12^{*}$ & 0.001 & 0.00004 \\
\hline 2-methylpentane & 0.252 & 0.560 & $2.85^{* r}$ & $0.14^{*}$ & 0.062 & 0.00356 \\
\hline methylcyclopentane & 0.053 & $0.56^{* m}$ & $2.85^{* r}$ & $0.14^{*}$ & 0.012 & 0.00067 \\
\hline hexane & 0.089 & 0.561 & $2.85^{* r}$ & $0.141^{x}$ & 0.022 & 0.00126 \\
\hline heptane & 0.088 & 0.715 & $2.85^{* r}$ & $0.178^{x}$ & 0.026 & 0.00201 \\
\hline octane & $0.022^{* \mathrm{C}}$ & 0.87 & $2.85^{* r}$ & $0.226^{x}$ & 0.007 & 0.00076 \\
\hline nonane & $0.011^{* c}$ & 1.02 & $2.85^{* r}$ & $0.25^{*}$ & 0.004 & 0.00049 \\
\hline \multicolumn{7}{|c|}{ Alkenes/alkynes/aromatics } \\
\hline ethene & $0.4^{* b}$ & 0.854 & 2 & $0.0086^{s}$ & 0.122 & 0.00053 \\
\hline $\mathrm{C}_{2} \mathrm{Cl}_{4}$ & 0.052 & 0.0173 & 2 & $0.01^{*}$ & 0.0003 & 0 \\
\hline propene & 0.125 & 2.63 & 2 & $0.015^{\mathrm{s}}$ & 0.126 & 0.00089 \\
\hline 1-butene & 0.014 & 3.14 & 2 & $0.025^{s}$ & 0.016 & 0.00020 \\
\hline methylpropene & 0.035 & 5.14 & 2 & $0.02^{*}$ & 0.063 & 0.00064 \\
\hline t2-butene & 0.003 & 6.40 & 2 & $0.03^{*}$ & 0.008 & 0.00012 \\
\hline c2-butene & 0.010 & 5.60 & 2 & $0.034^{s}$ & 0.019 & 0.00033 \\
\hline 3-methyl-1-butene & 0.015 & 3.18 & 2 & $0.03^{*}$ & 0.016 & 0.00025 \\
\hline 1-pentene & 0.017 & 3.14 & 2 & $0.05^{*}$ & 0.019 & 0.00049 \\
\hline t2-pentene & 0.006 & 6.70 & 2 & $0.05^{*}$ & 0.013 & 0.00034 \\
\hline 2-methyl-2-butene & 0.010 & 8.69 & 2 & $0.05^{*}$ & 0.022 & 0.00057 \\
\hline c2-pentene & 0.003 & 6.50 & 2 & $0.05^{*}$ & 0.006 & 0.00017 \\
\hline
\end{tabular}

\section{ACPD}

$5,4801-4843,2005$

\section{Total alkyl nitrates within the \\ Sacramento Urban Plume}

P. A. Cleary et al.

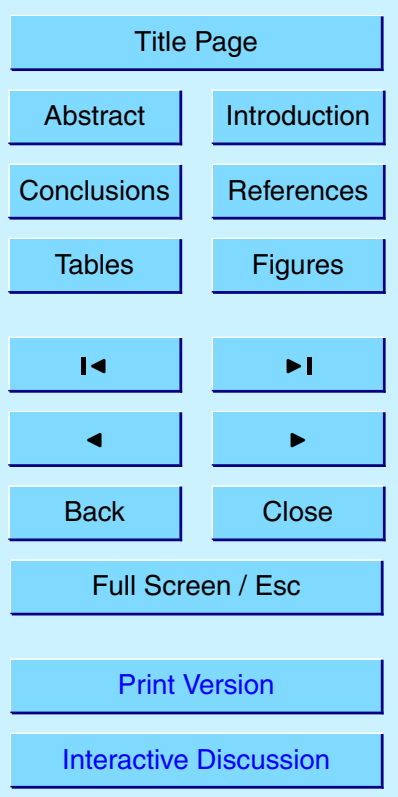


Table 1. Continued.

ACPD

\begin{tabular}{|c|c|c|c|c|c|c|}
\hline compound & $\begin{array}{l}\text { mixing ratio } \\
\text { (ppbv) }\end{array}$ & $\begin{array}{l}\mathrm{k}_{\mathrm{OH}}^{\mathrm{a}} \times 10^{11} \\
\text { molec. } \mathrm{cm}^{-3} \mathrm{~s}^{-1}\end{array}$ & $\gamma^{a}$ & $\alpha$ & 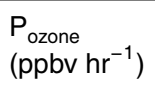 & $\begin{array}{l}\mathrm{P}_{\Sigma A N s} \\
\left(\mathrm{ppbv} \mathrm{hr}^{-1}\right)\end{array}$ \\
\hline \multicolumn{7}{|l|}{ Alkenes/alkynes/aromatics } \\
\hline cyclopentene & 0.002 & 6.70 & 2 & $0.05^{*}$ & 0.005 & 0.00011 \\
\hline benzene & 0.116 & 0.123 & 2 & $0.10^{*}$ & 0.005 & 0.00026 \\
\hline 1,2,4-trimethylbenzene & $0.070^{* \mathrm{C}}$ & 0.380 & 2 & $0.10^{*}$ & 0.068 & 0.00380 \\
\hline 1,3,5-trimethylbenzene & $0.024^{* \mathrm{C}}$ & 0.253 & 2 & $0.10^{*}$ & 0.046 & 0.00253 \\
\hline ethylbenzene & 0.052 & 0.710 & 2 & $0.10^{*}$ & 0.012 & 0.00067 \\
\hline 1,3-butadiene & 0.007 & 6.60 & 2 & $0.11^{t}$ & 0.015 & 0.00092 \\
\hline toluene & 0.347 & 0.596 & 2 & $0.10^{*}$ & 0.067 & 0.00372 \\
\hline o-xylene & 0.066 & 1.37 & 2 & $0.10^{*}$ & 0.029 & 0.00163 \\
\hline m-xylene & 0.104 & 2.36 & 2 & $0.10^{*}$ & 0.080 & 0.00443 \\
\hline p-xylene & 0.070 & 1.43 & 2 & $0.10^{*}$ & 0.032 & 0.00180 \\
\hline acetylene & $0.1^{* b}$ & 0.09 & 1.2 & $0.01^{*}$ & 0.002 & 0.00002 \\
\hline $\begin{array}{l}\text { propyne } \\
\text { Isoprene and oxidation } \\
\text { products }\end{array}$ & 0.016 & 0.592 & 0.24 & $0.05^{*}$ & 0.0004 & 0.00009 \\
\hline isoprene & 0.807 & 10.1 & 2 & $0.044^{\mathrm{u}}$ & 2.80 & 0.06452 \\
\hline methyl vinyl ketone & 0.570 & 1.88 & 2 & $0.05^{*}$ & 0.367 & 0.00965 \\
\hline methacrolein & 0.336 & 3.35 & $4^{* q}$ & $0.05^{*}$ & 0.962 & 0.01010 \\
\hline 3-methylfuran & 0.012 & $9.35^{\mathrm{k}}$ & 2 & $0.10^{*}$ & 0.034 & 0.00195 \\
\hline $\begin{array}{l}\text { hydroxycarbonyls } \\
\text { Terpenes }\end{array}$ & $0.53^{* d}$ & $1.1^{* \mathrm{~d}}$ & 2 & $0.03^{*}$ & 0.204 & 0.00315 \\
\hline$\alpha$-pinene & 0.013 & 5.37 & 2 & $0.18^{z}$ & 0.021 & 0.00233 \\
\hline limonene & 0.010 & 17.1 & 2 & $0.20^{*}$ & 0.050 & 0.00628 \\
\hline 3-carene & 0.003 & 8.80 & 2 & $0.20^{*}$ & 0.007 & 0.00082 \\
\hline$\beta$-pinene & $0.04^{* h}$ & 7.8 & 2 & $0.20^{*}$ & 0.090 & 0.01123 \\
\hline other terpenes & $0.04^{* i}$ & $7^{* i}$ & 2 & $0.20^{*}$ & 0.081 & 0.01008 \\
\hline $\begin{array}{l}\text { terpene oxidation } \\
\text { products } \\
\text { n-aldehydes }\end{array}$ & $0.07^{* i}$ & $1^{* i}$ & 2 & $0.20^{*}$ & 0.020 & 0.00252 \\
\hline formaldehyde & $4^{* f}$ & 0.937 & 1 & 0 & 0.675 & 0.00000 \\
\hline acetaldehyde & 1.318 & 1.58 & $3^{* q}$ & $0^{*}$ & 1.13 & 0.00000 \\
\hline propanal & $0.22^{* g}$ & 1.96 & 3 & $0.001^{*}$ & 0.232 & 0.00012 \\
\hline pentanal & 0.090 & $2.99^{n}$ & 3 & $0.01^{*}$ & 0.143 & 0.00048 \\
\hline hexanal & 0.134 & $3.17^{n}$ & 3 & $0.03^{*}$ & 0.222 & 0.00229 \\
\hline
\end{tabular}

5, 4801-4843, 2005

Total alkyl nitrates within the

\section{Sacramento Urban} Plume

P. A. Cleary et al.

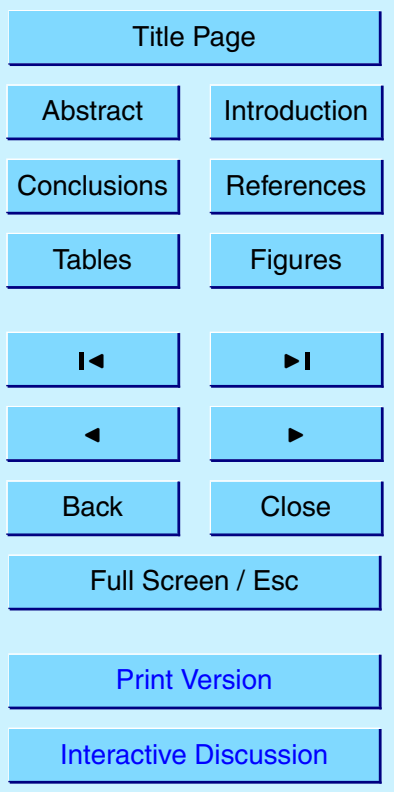


Table 1. Continued.

\begin{tabular}{|c|c|c|c|c|c|c|}
\hline compound & $\begin{array}{l}\text { mixing ratio } \\
(\mathrm{ppbv})\end{array}$ & $\begin{array}{l}\mathrm{k}_{\mathrm{OH}}^{\mathrm{a}} \times 10^{11} \\
\text { molec. } \mathrm{cm}^{-3} \mathrm{~s}^{-1}\end{array}$ & $\gamma^{\mathrm{a}}$ & $\alpha$ & $\begin{array}{l}P_{\text {ozone }} \\
\left(p p b v r^{-1}\right)\end{array}$ & 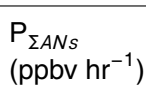 \\
\hline \multicolumn{7}{|l|}{ n-aldehydes } \\
\hline heptanal & $0.14^{* \mathrm{~g}}$ & $3.03^{* m}$ & 3 & $0.05^{*}$ & 0.222 & 0.00390 \\
\hline octanal & $0.13^{* g}$ & $3.17^{* m}$ & 3 & $0.07^{*}$ & 0.222 & 0.00558 \\
\hline nonanal & $0.23^{* g}$ & $3.6^{\mathrm{g}}$ & 3 & $0.20^{\mathrm{g}}$ & 0.445 & 0.03705 \\
\hline \multicolumn{7}{|l|}{ Oxygenated VOC } \\
\hline methyl ethyl ketone & 0.245 & 0.115 & 2 & $0.05^{*}$ & 0.010 & 0.00025 \\
\hline acetone & 3.196 & 0.0219 & 2 & $0.03^{*}$ & 0.025 & 0.00000 \\
\hline methanol & 7.142 & 0.094 & 2 & $0^{*}$ & 0.241 & 0.00000 \\
\hline ethanol & 1.783 & 0.327 & 2 & $0.0086^{*}$ & 0.208 & 0.00090 \\
\hline MTBE & 1.435 & 0.296 & 2 & $0.10^{*}$ & 0.137 & 0.00759 \\
\hline MBO & $0.175^{* j}$ & 3.9 & 2 & $0.03^{*}$ & 0.238 & 0.00369 \\
\hline glycoaldehyde & $0.16^{* j}$ & $1.1^{\circ}$ & 2 & $0.01^{*}$ & 0.062 & 0.00031 \\
\hline hydroxyacetone & $0.095^{* j}$ & $0.3^{p}$ & 2 & $0.01^{*}$ & 0.010 & 0.00005 \\
\hline glyoxal & $0.006^{* j}$ & $1.2^{p}$ & 2 & $0.01^{*}$ & 0.003 & 0.00001 \\
\hline methyl glyoxal & $0.03^{* j}$ & $1.7^{\mathrm{p}}$ & 2 & $0.01^{*}$ & 0.018 & 0.00009 \\
\hline 2-hydroxy- & $0.0 .053^{* j}$ & $2.0^{\mathrm{p}}$ & 2 & $0.01^{*}$ & 0.038 & 0.00019 \\
\hline \multirow{2}{*}{\multicolumn{7}{|c|}{ 2-methylpropanal }} \\
\hline & \\
\hline IANs & 0.7 & 1.6 & 2 & $0.06^{*}$ & 0.379 & 0.01210 \\
\hline $\mathrm{CO}$ & $190^{*}$ & 0.015 & 1 & 0 & 0.821 & 0.00000 \\
\hline \multicolumn{7}{|l|}{ Photolysis } \\
\hline formaldehyde & 4 & $3 \times 10^{-5}$ & 2 & 0 & 0.864 & 0.00000 \\
\hline acetone & 3.423 & $5.3 \times 10^{-7}$ & 5 & 0 & 0.011 & 0.00000 \\
\hline Total & & & & & 12.5 & 0.242 \\
\hline
\end{tabular}

ACPD

5, 4801-4843, 2005

\section{Total alkyl nitrates within the \\ Sacramento Urban Plume}

P. A. Cleary et al.

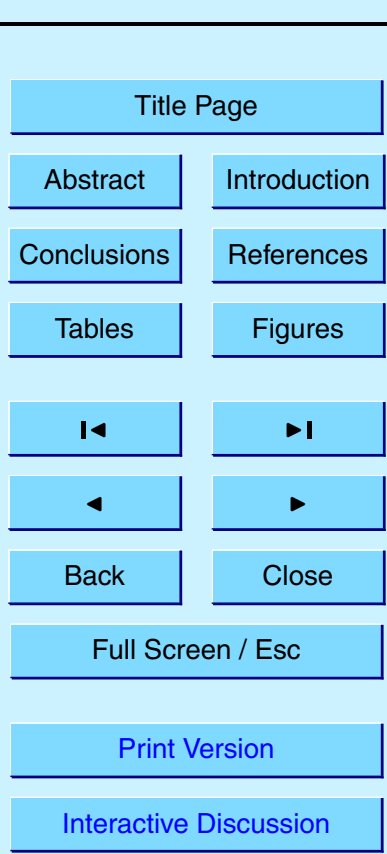

al. (2003); ${ }^{g}$ estimated abundances from Hurst Bowman et al. (2003), where the reactivities of heptanal, propanal and octanal are equal to the reactivity to that of hexanal and the reactivity of nonanal is twice that of hexanal. The rate coefficient, $\mathrm{k}_{\mathrm{OH}}$, for nonanal is as measured by Hurst Bowman et al. (2003); ${ }^{\mathrm{h}}$ estimated from McKeen et al. (1997), where $[\beta$-pinene $]=3 \times[\alpha$-pinene $]$; ${ }^{i}$ other terpenes estimated as $=\beta$-pinene with $\mathrm{OH}$ rate constant $\sim \beta$-pinene reaction rate, terpene oxidation products are estimated $=60 \%$ of total terpenes; 
${ }^{j}$ estimated from measurements taken by Spaulding et al. (2003) at Blodgett Forest at $\sim 0.25 \times$ the Blodgett Forest abundances for all species; ${ }^{k}$ Atkinson et al. (1989); ${ }^{\mathrm{H}}$ Hsu and Demore (1994); ${ }^{\mathrm{m}}$ estimated from Kwok and Atkinson (1995); ${ }^{\mathrm{n}}$ Papagni et al. (2000); ${ }^{\circ}$ Bacher et al. (2001); ${ }^{\mathrm{P}}$ Spaulding et al. (2003) and references therein; ${ }^{9}$ PAN and MPAN are assumed to be in steady state with their production from acetaldehyde and methacrolein, thus the peroxyacetyl nitrate formation is considered a temporary reservoir and the total $\mathrm{O}_{3}$ molecules generated per oxidation of aldehyde includes those formed from the net loss of

5 PAN and MPAN (Cleary, 2003); ${ }^{r}$ estimated from the photooxidation mechanism for n-butane from Seinfeld et al. (1998); ${ }^{\mathrm{s}}$ O'Brien et al. (1998); ${ }^{\mathrm{t}}$ Sprengnether et al. (2002); ${ }^{\mathrm{u}}$ Chen et al. (1998); ${ }^{\mathrm{V}}$ Ranschaert et al. (2000); ${ }^{\mathrm{w}}$ Atkinson et al. (1982); ${ }^{\mathrm{X}}$ Arey et al. (2001); ${ }^{\mathrm{y}}$ Lightfoot et al. (1992) and references therein; ${ }^{\mathrm{z}}$ Noziere et al. (1999). ${ }^{\dagger}$ Photolysis rates are calculated as an average from between 08:00-12:00 $\mathrm{h}$ using the TUV model (UCAR, 2002). ${ }^{\ddagger}$ in s ${ }^{-1}$.
ACPD

5, 4801-4843, 2005

Total alkyl nitrates

within the

\section{Sacramento Urban}

Plume

P. A. Cleary et al.

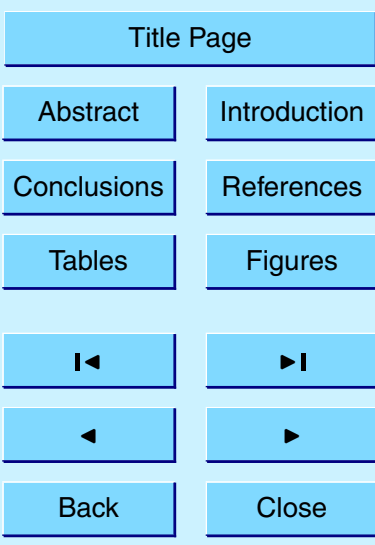

Full Screen / Esc

Print Version

Interactive Discussion 


\section{ACPD}

Table 2. Summary of ozone and $\Sigma A N$ production by major categories of VOC.

\begin{tabular}{lccccc}
\hline Compound & $\mathrm{ppb}$ & $\begin{array}{c}\mathrm{P}_{\text {ozone }} \\
\left(\mathrm{ppbv} \mathrm{hr}{ }^{-1}\right)\end{array}$ & $\% \mathrm{P}_{\text {ozone }}$ & $\begin{array}{c}\mathrm{P}_{\Sigma A N s} \\
\left(\mathrm{ppbv} \mathrm{hr}^{-1}\right)\end{array}$ & $\% \mathrm{P}_{\Sigma A N s}$ \\
\hline Alkanes & 5.47 & 0.392 & 3.1 & 0.020 & 8.0 \\
Alkenes/alkynes/aromatics & 1.63 & 0.779 & 6.2 & 0.024 & 10.1 \\
Isoprene & 0.886 & 2.80 & 22.4 & 0.065 & 26.7 \\
Isoprene oxidation products & 1.39 & 1.57 & 12.5 & 0.025 & 10.3 \\
Terpenes + oxidation products & 0.071 & 0.269 & 2.1 & 0.033 & 13.5 \\
Aldehydes & 1.56 & 2.61 & 20.8 & 0.049 & 20.4 \\
Other OVOC & 13.7 & 0.990 & 8.0 & 0.013 & 5.4 \\
Formaldehyde & 4.0 & 1.54 & 12.3 & 0.00 & 0 \\
CO + $\mathrm{CH}_{4}$ & 1900 & 1.20 & 9.6 & 0.00 & 0 \\
Organic Nitrates & 0.7 & 0.379 & 3.0 & 0.012 & 5.0 \\
\hline Total & & 12.5 & 100 & 0.242 & 100 \\
\hline
\end{tabular}

$5,4801-4843,2005$

Total alkyl nitrates within the

\section{Sacramento Urban} Plume

\section{P. A. Cleary et al.}

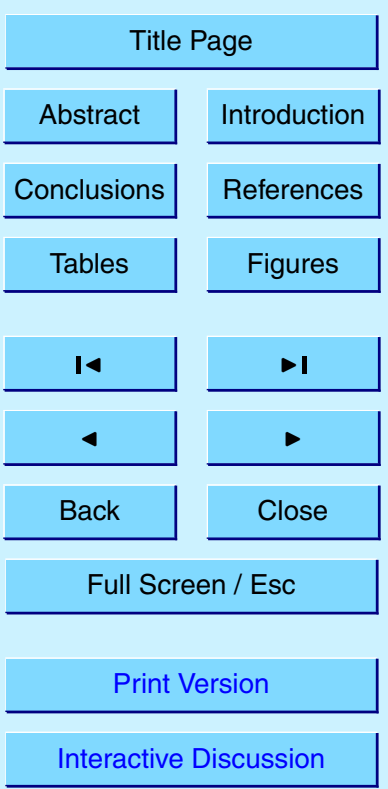




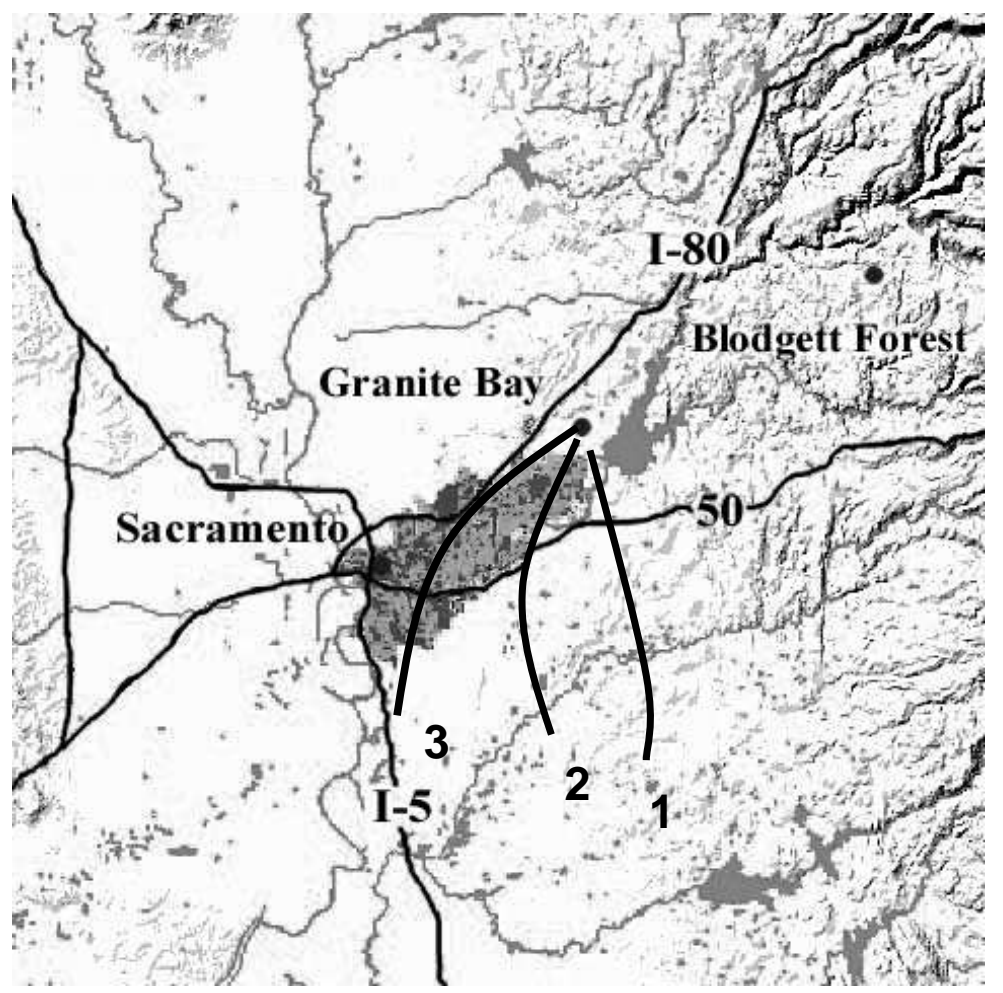

Fig. 1. Topographical map of Sacramento and surrounding areas. Three locations, downtown Sacramento, Granite Bay and UC-BFRS are indicated with black dots. The Granite Bay research site is located 20 miles from the Sacramento urban core, on the outskirts of the Sacramento suburbs. The Blodgett forest research station is located 20 miles to the NE of the Granite Bay site. The major highways, routes 5,50 and 80 , rivers and reservoirs are shown. The gray region around the Sacramento metropolitan area (total population $=1.6$ million) marks the region of population density greater than 1900 people $\mathrm{km}^{-2}$. The trajectory lines represent the $4 \mathrm{~h}$ back trajectories for air parcels arriving at the site at 08:00 LT (1), 10:00 LT (2) and 12:00 LT (3).
ACPD

$5,4801-4843,2005$

Total alkyl nitrates within the

\section{Sacramento Urban} Plume

P. A. Cleary et al.

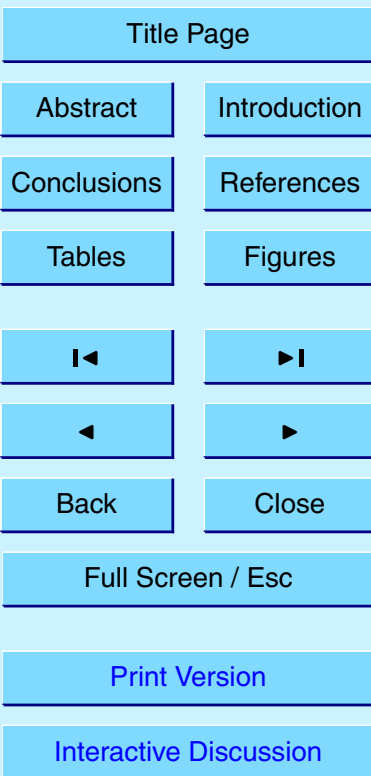

EGU 


\section{ACPD}

$5,4801-4843,2005$

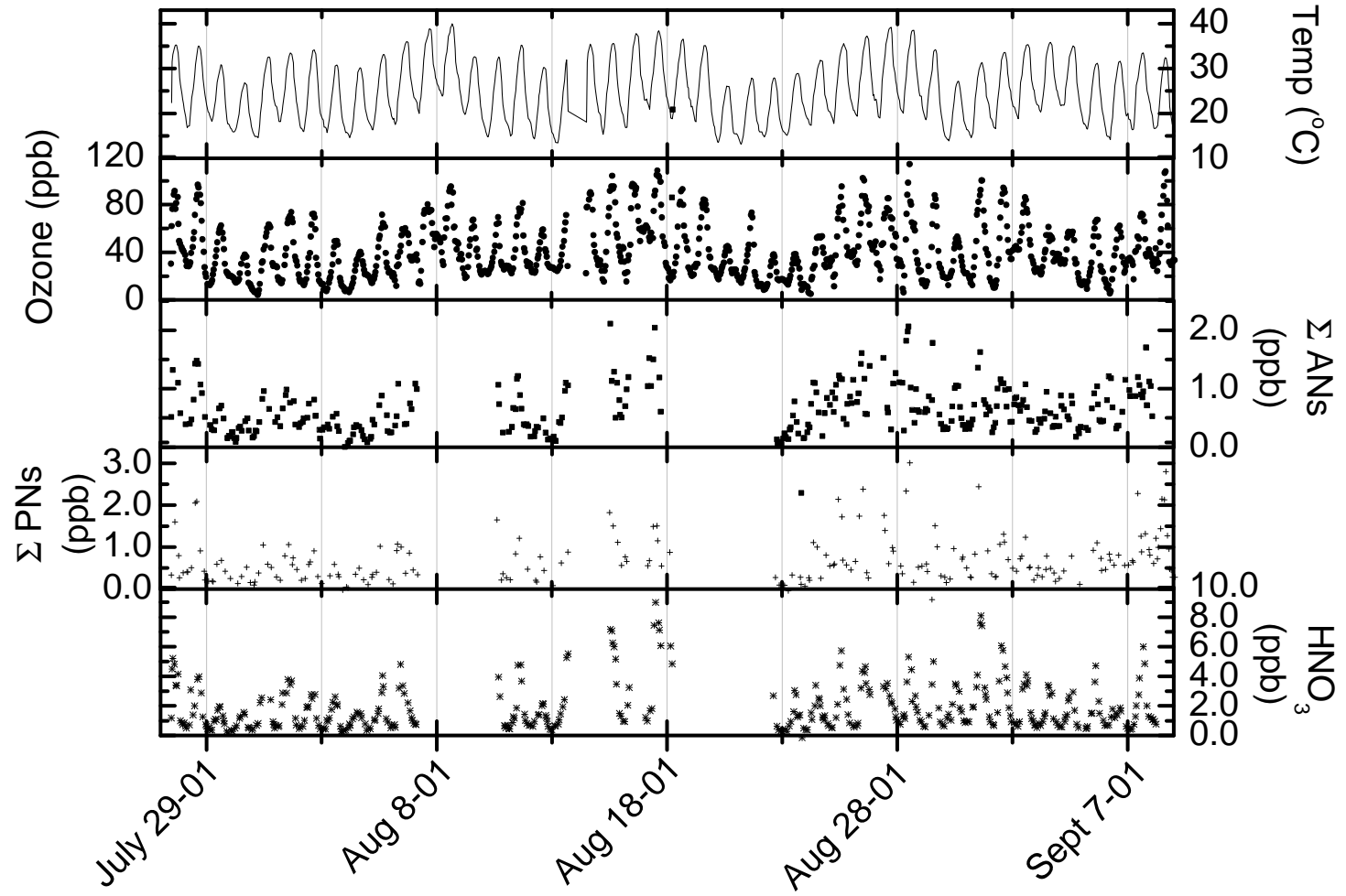

\section{Total alkyl nitrates within the \\ Sacramento Urban \\ Plume}

P. A. Cleary et al.

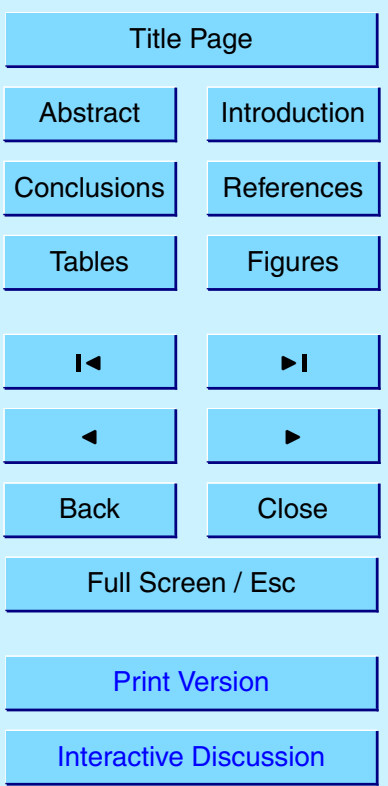

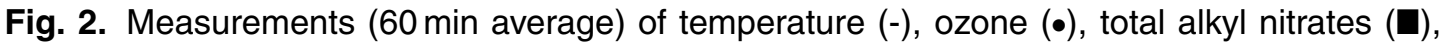
total peroxy nitrates (+), and nitric acid $\left(^{*}\right)$ from 27 July to 9 September 2001. 


\section{ACPD}

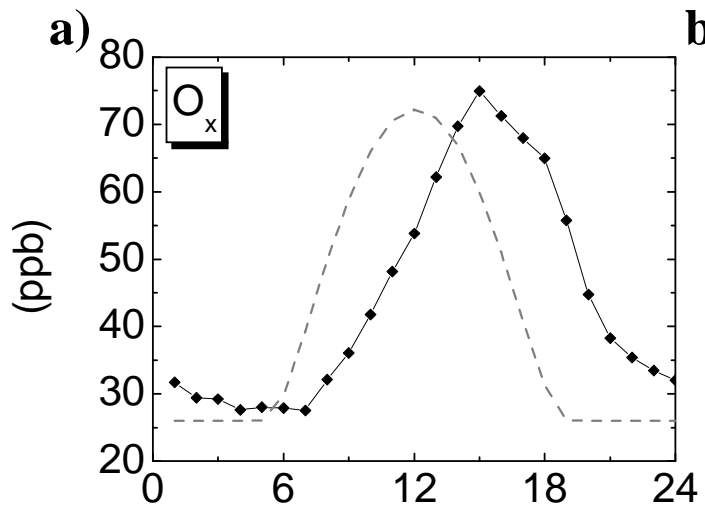

b)

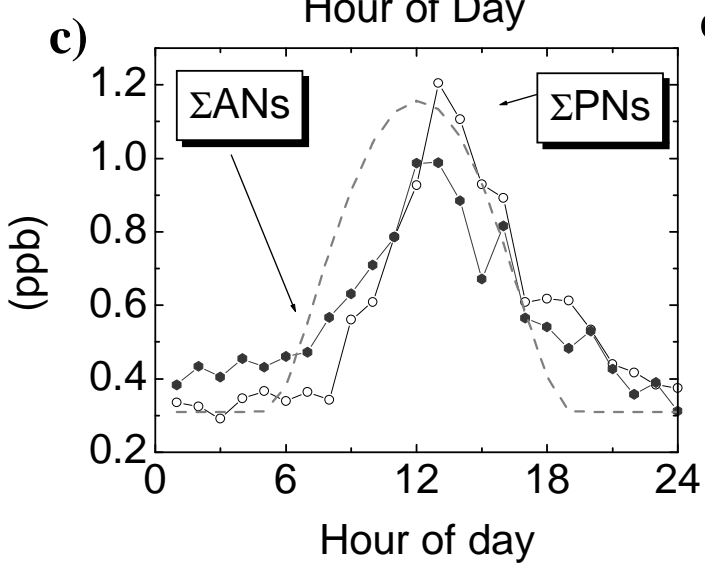

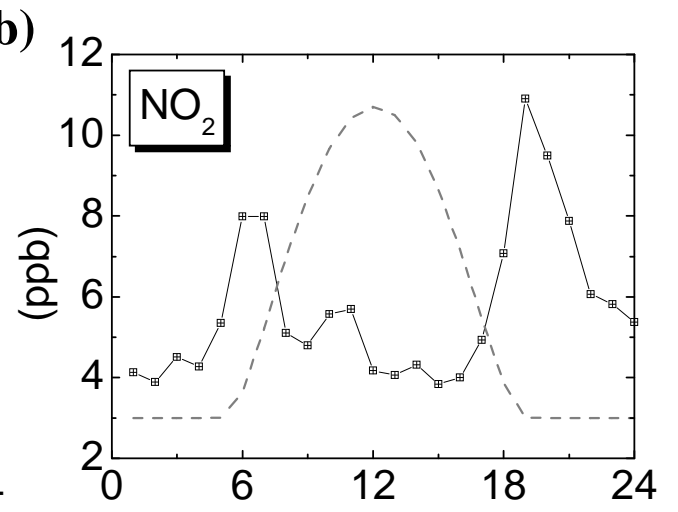

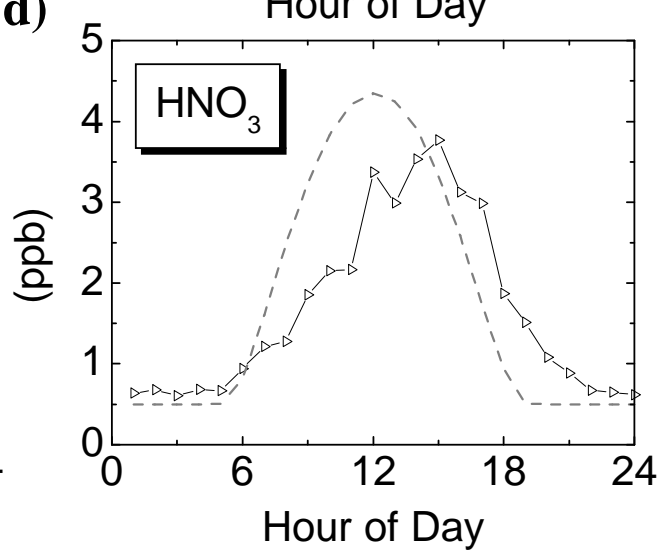

Fig. 3. The median diurnal measurements of (a) $\mathrm{O}_{\mathrm{x}}\left(\mathrm{O}_{3}+\mathrm{NO}_{2}\right)$, (b) $\mathrm{NO}_{2}$, (c) $\Sigma \mathrm{PNs}(-\bullet-)$ and $\Sigma$ ANs (-), (d) $\mathrm{HNO}_{3}$ with PAR representing solar flux (--).

$5,4801-4843,2005$

Total alkyl nitrates within the

\section{Sacramento Urban}

Plume

P. A. Cleary et al.

Title Page

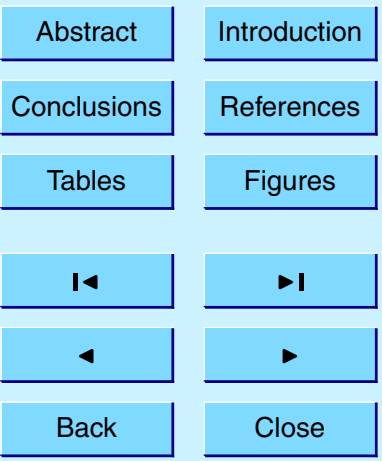

Full Screen / Esc

Print Version

Interactive Discussion 


\section{ACPD}

\section{HO Cycle}

$5,4801-4843,2005$

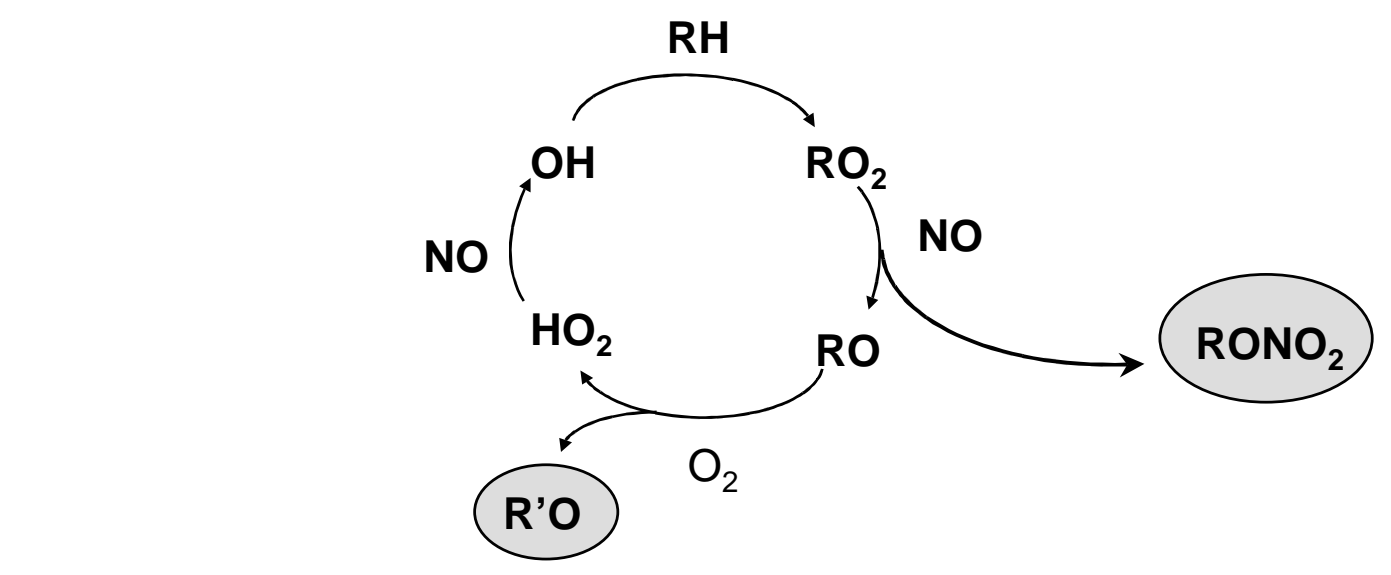

NO Cycle

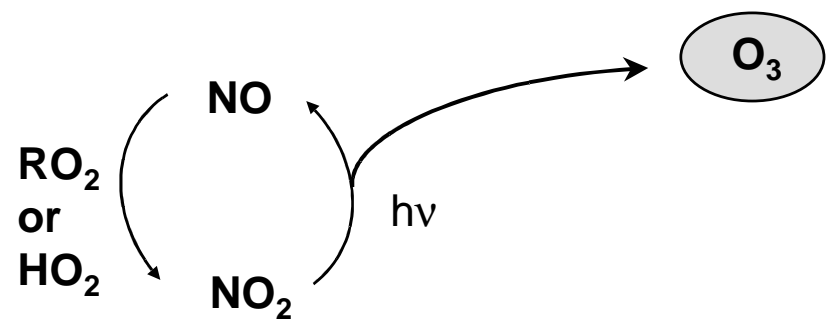

Total alkyl nitrates within the

\section{Sacramento Urban}

Plume

P. A. Cleary et al.

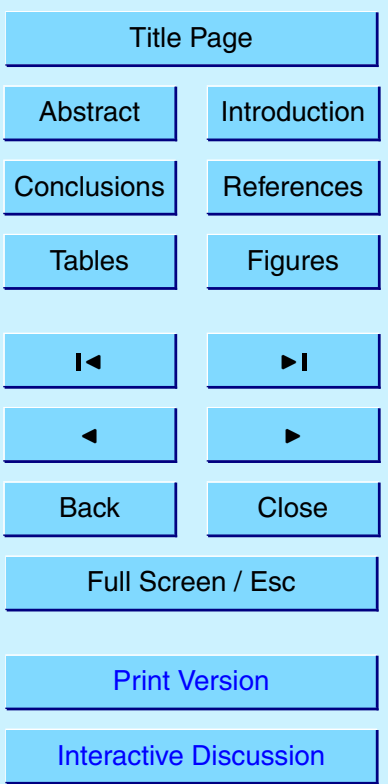

Fig. 4. A schematic diagram of tropospheric $\mathrm{HO}_{x}$ and $\mathrm{NO}_{x}$ cycles. Ozone, alkyl nitrates, and carbonyl compounds are products of the coupling of both cycles. Typically, as shown in this figure, two molecules of ozone are produced per VOC oxidized. 


\section{ACPD}

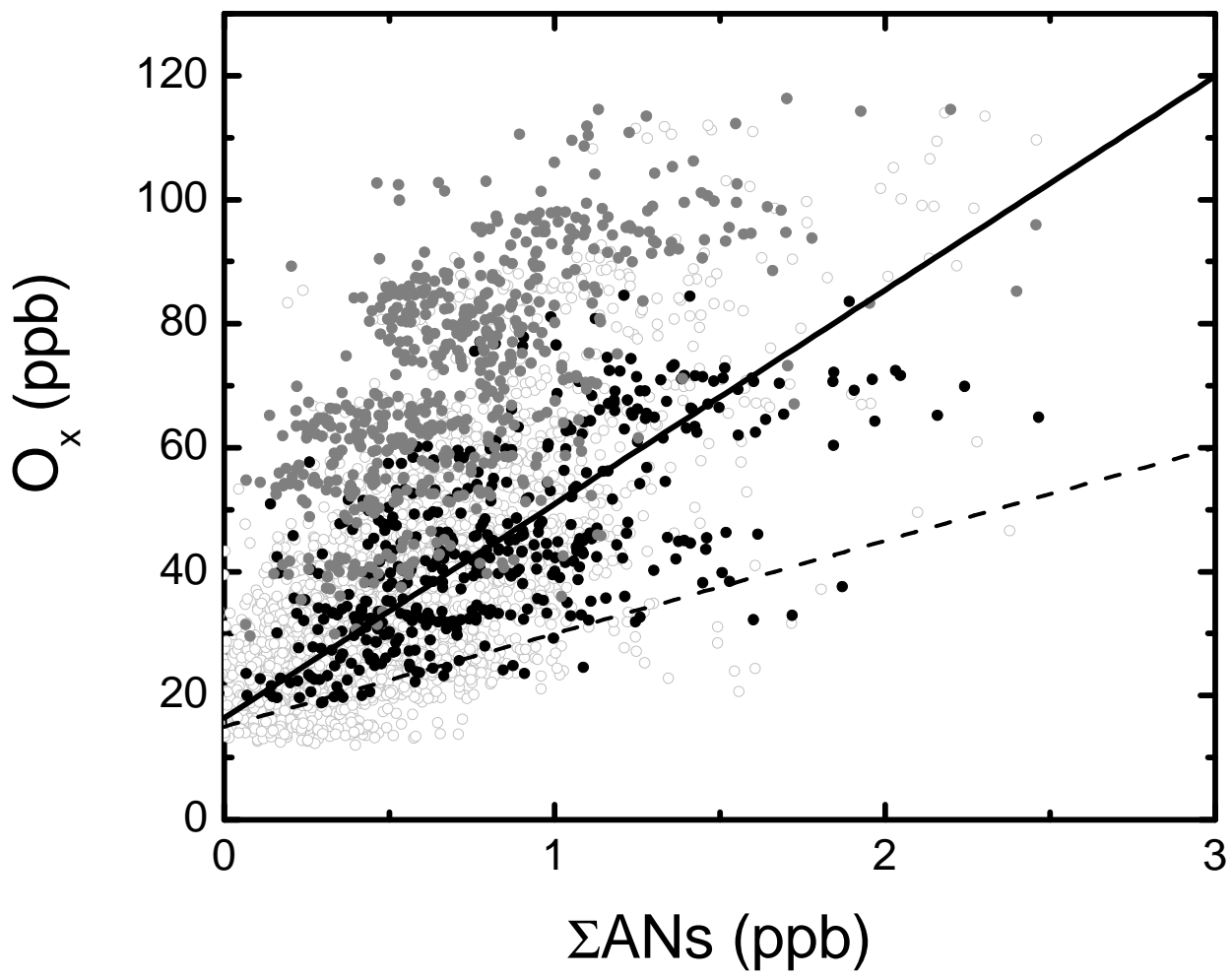

5, 4801-4843, 2005

Total alkyl nitrates within the

\section{Sacramento Urban}

Plume

P. A. Cleary et al.

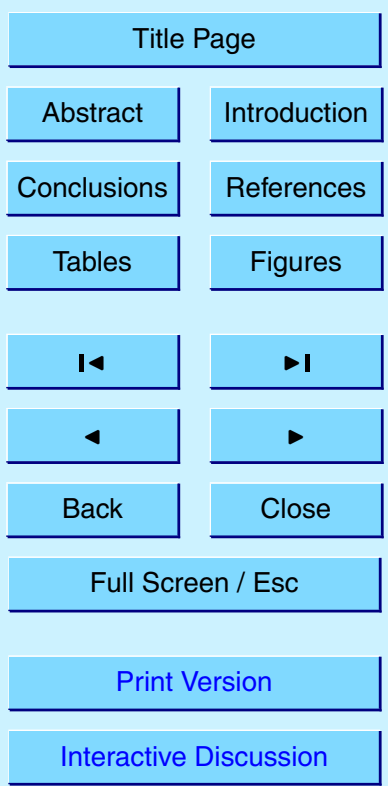

Fig. 5. Observations of $O_{x}$ versus $\Sigma$ ANs. All points (०), 09:00-12:00 (solid black, •), 14:0018:00 (grey, •). The solid line represents the linear regression fits to the 09:00-12:00 data $(y=34.6 x+16.4)$. The dashed line represents a minimum slope for the 09:00-12:00 data $(y=15 x+15)$. 


\section{ACPD}

5, 4801-4843, 2005

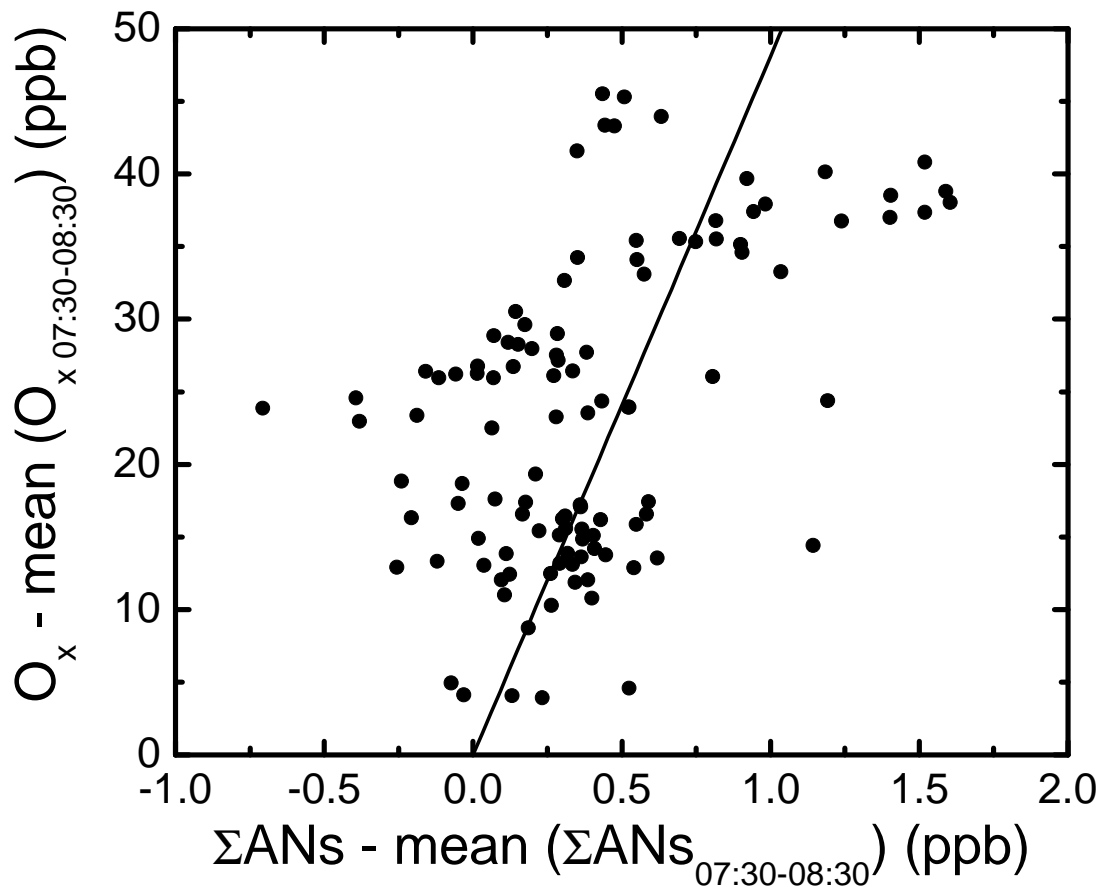

Total alkyl nitrates within the

\section{Sacramento Urban}

Plume

P. A. Cleary et al.

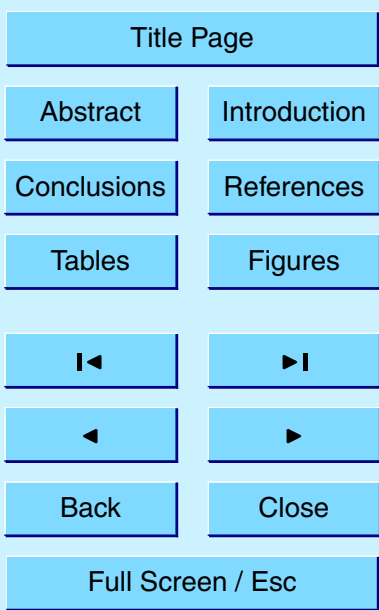

observations from 10:30-12:00 $\mathrm{h}$ are plotted.

Print Version

Interactive Discussion 
a)

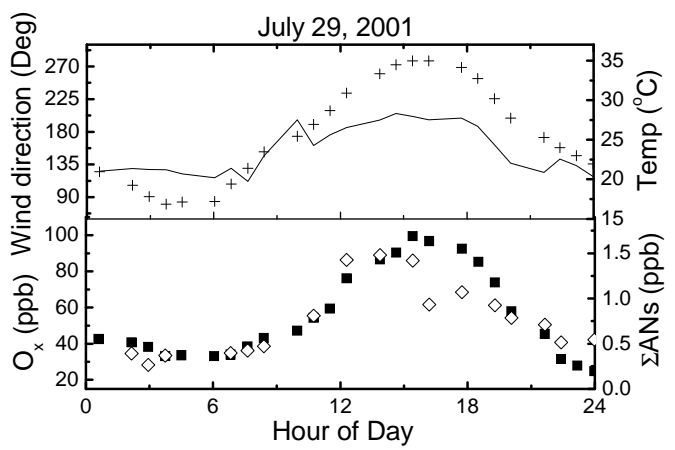

b)

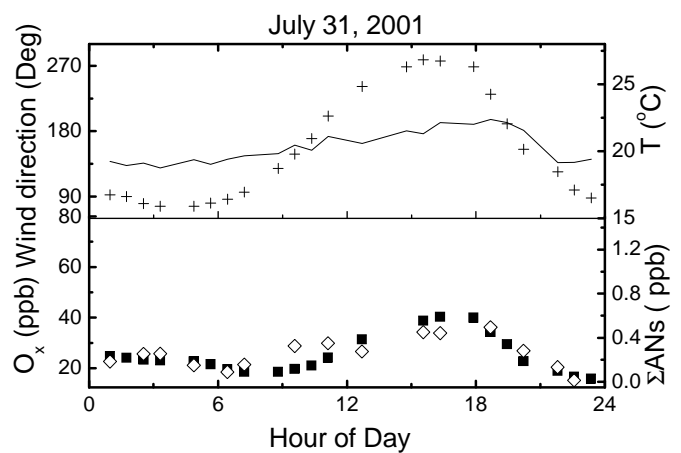

c)

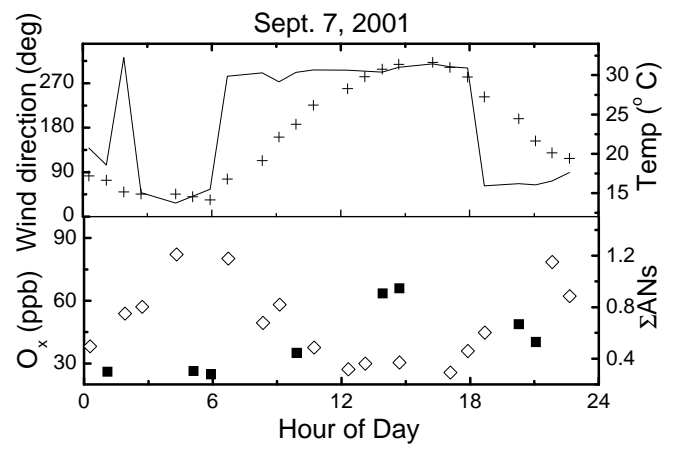

Fig. 7. Three example days of the rise in EANs $(\diamond)$ and $\mathrm{O}_{x}$ (घ) along with wind direction (-) and temperature (+): (a) 29 July 2001 where the winds change smoothly from southeasterlies $\left(100^{\circ}\right)$ to southwesterlies $\left(200^{\circ}\right)$, a high temperature of $35^{\circ} \mathrm{C}$ and maximum $\mathrm{O}_{\mathrm{x}}$ and $\Sigma \mathrm{ANs}$ of 100 and $1.5 \mathrm{ppbv}$, respectively; (b) 31 July 2001 where the winds shift slowly over to southwesterlies later in the evening with a high temperature of $27^{\circ} \mathrm{C}$, and maximum $\mathrm{O}_{x}$ and $\Sigma$ ANs of 40 and $0.5 \mathrm{ppbv}$, respectively; and (c) 7 September 2001 where the winds change abruptly in the early morning from north easterlies $\left(45^{\circ}\right)$ to westerlies $\left(270^{\circ}\right)$ with a high temperature of $31^{\circ} \mathrm{C}$ and maximum $\mathrm{O}_{\mathrm{x}}$ and $\Sigma \mathrm{ANs}$ of 65 and $1.2 \mathrm{ppbv}$, respectively. The $\Sigma$ ANs peak in the early morning on this day and are at a minimum at noon at $0.30 \mathrm{ppbv}$.
ACPD

5, 4801-4843, 2005

Total alkyl nitrates within the

\section{Sacramento Urban} Plume

P. A. Cleary et al.

\section{Title Page}

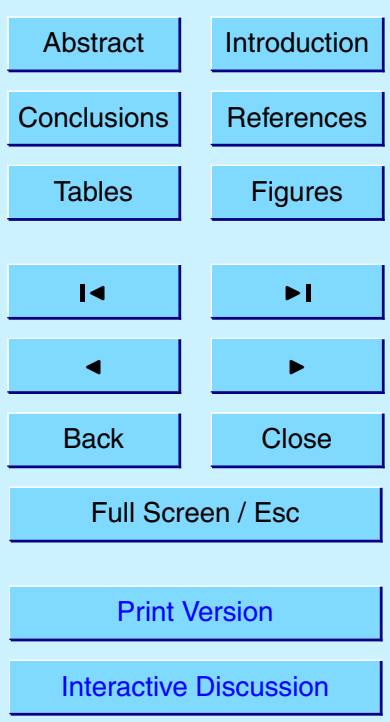

EGU 